\title{
EFICIÊNCIA E POTENCIAL DE EXPANSÃo dA EDUCAÇão SUPERIOR PÚBLICA
}

\author{
Luiz Carlos Zalaf Caseiro ${ }^{\mathrm{I}}$
}

Alexandre Ramos de Azevedo II

http://dx.doi.org/10.24109/9786581041076.ceppe.v2a3

\section{RESUMO}

A distribuição da escolarização de nível superior contribui para estruturar as desigualdades na sociedade brasileira. Em comparação a outros países, o Brasil apresenta baixo percentual da população adulta diplomada e um dos maiores prêmios salariais do mundo. A necessidade de expansão da educação superior foi reconhecida pelo Estado e pela sociedade civil na elaboração do Plano Nacional de Educação (PNE), cujo cumprimento requer, entre outras medidas, dobrar as matrículas nos cursos públicos de graduação até o ano de 2024. Para atingir esse objetivo, o PNE prevê a adoção de estratégias de criação de novas vagas e de aumento da eficiência na utilização da capacidade instalada nas instituições de ensino superior (IES) públicas. Este artigo tem dois objetivos. O primeiro é a construção de indicadores de eficiência, baseados em estratégias do PNE e relativos à: a) ociosidade de vagas; b) conclusão, desistência e permanência; e c) oferta de vagas no período noturno. O segundo objetivo

\footnotetext{
I Doutorando em sociologia pela Universidade de São Paulo, pesquisador do Instituto Nacional de Estudos e Pesquisas Educacionais Anísio Teixeira (Inep), atua na Diretoria de Estudos Educacionais (Dired). E-mails: luiz.caseiro@inep.gov.br e luizzalaf@gmail.com

II Mestre em educação pela Universidade do Estado do Rio de Janeiro, pesquisador do Instituto Nacional de Estudos e Pesquisas Educacionais Anísio Teixeira (Inep), atua na Diretoria de Estudos Educacionais (Dired).E-mails: alexandre.azevedo@inep.gov.br e somaralex@gmail.com
} 
é verificar o quanto as matrículas nas IES públicas podem ser ampliadas mediante as estratégias de melhoria dos indicadores de eficiência. Para isso, foram construídos cenários que estimam a necessidade de criação de novas vagas junto com a otimização da capacidade instalada no sistema. Concluiu-se que mesmo se a eficiência das IES públicas aumentar de maneira substantiva, ainda assim, é necessária a criação de novas vagas para cumprir as metas do PNE e tornar a educação superior brasileira mais acessível para a população.

Palavras-chave: educação superior; expansão do ensino superior; Plano Nacional de Educação.

\section{INTRODUÇÃO}

Este artigo apresenta uma proposta de indicadores complementares ao monitoramento da Meta 12 do Plano Nacional de Educação (PNE), permitindo uma análise prospectiva dos esforços necessários para alcançar os objetivos de expansão da oferta e do acesso aos cursos de graduação no Brasil. Esses indicadores inovam ao contemplar não só aspectos da cobertura da política de educação superior, em termos do número de alunos e matrículas, mas também ao estimar a eficiência na utilização da capacidade instalada do sistema de ensino.

Análises preliminares da evolução dos indicadores da Meta 12, apresentadas nos relatórios de monitoramento do PNE (Brasil. Inep, 2016, 2018), incluíram recortes específicos que permitiram visualizar a evolução recente das desigualdades sociais no acesso à graduação e da expansão da oferta nas diversas redes, modalidades de ensino e áreas do conhecimento. Nesses trabalhos pretendeu-se contribuir para o monitoramento de algumas estratégias da Meta 12, notadamente aquelas relacionadas aos temas da redução das desigualdades educacionais - Estratégias 12.5 e 12.9 - e da expansão do segmento público - Estratégias 12.1, 12.2 e 12.4 (Brasil, 2014). Com base em novas discussões sobre o monitoramento dessa Meta, realizadas entre o Instituto Nacional de Estudos e Pesquisas Educacionais Anísio Teixeira (Inep), as entidades legais responsáveis (Brasil, 2014, art. 5º e a sociedade civil (Brasil. Inep, 2015a), constatou-se a necessidade de análises complementares, incluindo aspectos da cobertura e da eficiência da expansão do ensino. O objetivo deste artigo é contribuir para a discussão sobre a eficiência do sistema de educação superior, com ênfase no segmento público, priorizado pelo PNE.

São propostos, neste trabalho, cinco indicadores complementares para o monitoramento da Meta 12. Esses indicadores baseiam-se em estratégias do PNE voltadas para a otimização da capacidade instalada nas instituições de ensino superior 
(IES) públicas. São eles: a) taxa de ociosidade em vagas iniciais (Estratégia 12.17); b) taxas médias de conclusão, desistência e permanência (Estratégia 12.3); e c) potencial de expansão da educação superior com a ampliação da oferta de vagas em cursos noturnos (Estratégia 12.3).

A escolha por analisar essas estratégias, referentes à otimização da capacidade instalada nas IES públicas, não ocorre em detrimento das demais estratégias do PNE para a educação superior. Os autores deste artigo fazem parte da equipe técnica do Inep responsável pela produção de estudos de monitoramento do Plano e já produziram, em ocasiões anteriores, estudos referentes às estratégias de redução das desigualdades de acesso à graduação (Caseiro, 2016a) e sobre qualidade na educação superior (Azevedo, 2016).

Ademais, o aumento da eficiência no acesso e na conclusão da educação superior também possui uma importante relação com a redução das desigualdades existentes na sociedade brasileira. O relatório Education at Glance, da Organização para a Cooperação e Desenvolvimento Econômico - OCDE (2018), compara indicadores educacionais de 46 países, incluindo os países-membros e os 20 países de maior Produto Interno Bruto (PIB) do mundo. Nesses indicadores, o Brasil aparece como o quarto país com o menor percentual de adultos com diploma de nível superior e com o mais elevado prêmio salarial para a educação terciária dentre todos os países (Tabela 1). O prêmio salarial mensura a razão entre a média salarial daqueles que concluíram a graduação e a média salarial dos que possuem apenas o ensino médio completo. No Brasil, o salário das pessoas que completaram a graduação é três vezes e meia maior do que o salário das pessoas que completaram apenas o ensino médio.

TABELA 1

EDUCAÇÃO SUPERIOR E DESIGUALDADE NO MUNDO

\begin{tabular}{|l|c|c|}
\hline \multicolumn{1}{|c|}{ Países e Regiões } & $\begin{array}{c}\text { População de 25 a 34 anos com } \\
\text { diploma de nível superior }\end{array}$ & $\begin{array}{c}\text { Prêmio salarial } \\
\text { da educação superior }\end{array}$ \\
\hline Brasil & $17 \%$ & $249 \%$ \\
\hline Média OCDE & $44 \%$ & $154 \%$ \\
\hline Média União Europeia & $42 \%$ & $151 \%$ \\
\hline Alemanha & $31 \%$ & $169 \%$ \\
\hline Chile & $30 \%$ & $237 \%$ \\
\hline Colômbia & $28 \%$ & $236 \%$ \\
\hline Estados Unidos & $48 \%$ & $175 \%$ \\
\hline França & $44 \%$ & $155 \%$ \\
\hline Itália & $27 \%$ & $138 \%$ \\
\hline Japão & $60 \%$ & $152 \%$ \\
\hline México & $23 \%$ & $195 \%$ \\
\hline Reino Unido & $52 \%$ & $150 \%$ \\
\hline
\end{tabular}

Fonte: Elaboração própria com base em dados de OECD (2018). 
Esses dados indicam que o diploma de graduação ainda é um bem relativamente escasso e contribui para estruturar as desigualdades na sociedade brasileira. Ampliar as oportunidades de acesso e de conclusão dos cursos superiores pode, portanto, contribuir para a redução das desigualdades na sociedade como um todo - mesmo que esse efeito seja limitado por fatores estruturais do mercado de trabalho e da estrutura produtiva brasileira (Medeiros; Barbosa; Carvalhaes, 2019). A melhoria dos indicadores de eficiência propostos pelo PNE e analisados neste trabalho pode ter um impacto nessa direção. Estudos realizados no Brasil (Brito, 2014; Ribeiro; Ceneviva; Brito, 2015) e em outros países (Bound; Turner, 2011; Tinto, 2012) indicam que a probabilidade de conclusão dos cursos de graduação encontra-se correlacionada a fatores socioeconômicos, como escolaridade e ocupação dos pais, renda familiar e cor/raça. Nesse sentido, a elevação das taxas de conclusão da graduação pode contribuir para a obtenção de diploma de indivíduos de grupos sociais historicamente desfavorecidos. De modo semelhante, os cursos noturnos também são ocupados majoritariamente por alunos com menor nível socioeconômico (Pacheco; Ristoff, 2004; Bittar; Almeida; Veloso, 2008). A ampliação da oferta e das condições de permanência nesse turno pode contribuir para a redução das desigualdades educacionais.

Duas importantes ressalvas precisam ser feitas em relação aos indicadores apresentados neste capítulo. A primeira é que tratamos da eficiência nas IES públicas apenas no que tange à utilização, por alunos de graduação, da capacidade instalada, nos termos das estratégias da Meta 12 do PNE. A segunda ressalva é que esses dados são ainda preliminares e, portanto, precisam ser replicados e acompanhados por estudos mais aprofundados, antes que possam ser utilizados para subsidiar políticas públicas. Nosso objetivo aqui é apenas descritivo, de investigar e descrever regularidades estatísticas do sistema de educação superior brasileiro, de modo a tornar sua realidade mais conhecida. A identificação dessas regularidades possibilita o levantamento de hipóteses a respeito de causas que precisam ser testadas por estudos adicionais.

A constatação de que o acesso à educação superior no Brasil é mais baixo do que em muitos países conduz à pergunta sobre o quanto esse acesso precisaria ser ampliado. Embora não haja uma resposta incontestável para essa questão, o PNE oferece uma explicação possível e que foi pactuada pelo Estado brasileiro e por diversos atores da sociedade civil organizada (Dourado, 2016). Na próxima seção deste artigo, procura-se realizar um diagnóstico do quão distante o País se encontra de cumprir as metas do PNE para expansão da educação superior. Na terceira seção, são apresentados os indicadores de eficiência previamente mencionados. Na seção seguinte, são realizados exercícios de simulação com base em novos indicadores propostos para avaliar cenários tendo em vista o cumprimento da meta do PNE, mediante o aumento da eficiência na utilização da capacidade instalada nas IES públicas. 


\section{A META DO PNE PARA AMPLIAÇÃO DA EDUCAÇÃO SUPERIOR}

O primeiro passo para o desenho de políticas públicas com vistas ao cumprimento dos objetivos previstos na Meta 12 do PNE é identificar o quão distante o País se encontra desses alvos. Assim, retoma-se a redação do cabeçalho da Meta 12, em que são listados três objetivos para a expansão do acesso e da oferta dos cursos de graduação no Brasil:

1. Elevar a taxa bruta de matrículas na educação superior para $50 \%$.

2. Elevar a taxa líquida de matrículas para 33\% da população de 18 a 24 anos.

3. Assegurar a expansão para, pelo menos, $40 \%$ das novas matrículas no segmento público.

As taxas brutas e líquidas de matrículas são indicadores que buscam mensurar a oferta e o acesso à graduação em relação à população considerada pertencente à idade de referência para cursar determinado nível de ensino (Saraiva, 2010a, 2010b; Unesco, 2017). Essas taxas, assim como a maioria dos indicadores sociais, procuram traduzir conceitos abstratos, de interesse teórico ou para a formulação de políticas públicas (Jannuzzi, 2001). Mas, por refletirem conceitos abstratos, nem sempre esses indicadores possibilitam uma apreensão imediata do quanto falta realizar, em termos concretos, para que sejam alcançados os objetivos estipulados.

Formalmente, a taxa bruta de matrículas (TBM) é calculada pela razão entre o número de matrículas, ou de alunos na educação superior, e a quantidade de pessoas com idade entre 18 e 24 anos existente no País, ou a população demandante potencial. ${ }^{1}$ Assim, elevar a TBM do ensino superior a 50\% significa que o número de pessoas que devem frequentar a graduação em 2024 precisará ser, no mínimo, a metade da população de 18 a 24 anos de idade. Tendo em vista a tendência atual de diminuição da população dessa faixa etária (IBGE, 2018), uma estimativa conservadora pode ser obtida com os dados mais recentes da Pesquisa Nacional por Amostra de Domicílios Contínua (Pnad Contínua). ${ }^{2}$

A população que precisa ser incluída na graduação, para alcançar a TBM determinada pelo PNE, pode ser estimada pela Equação 1:

\footnotetext{
1 Uma discussão a respeito das diferenças entre a utilização de matrículas ou de alunos para o cálculo da TBM pode ser encontrada em Caseiro e Azevedo (2018).

2 A estimativa oficial disponível da população futura é dada pelas projeções populacionais do IBGE (IBGE, 2018). O cálculo das matrículas necessárias para cumprir a meta do PNE com base nessas projeções revisão de 2013 - foi feito por Caseiro (2016a). Entretanto, as informações fornecidas pelas projeções populacionais para a faixa etária de 18 a 24 anos são diferentes das informações populacionais da Pnad Contínua, utilizadas para o monitoramento anual da TBM e da taxa líquida de escolarização. A escolha por utilizar a Pnad Contínua mantém a coerência das decisões tomadas, até o momento, no monitoramento da Meta 12, em especial a opção por não combinar duas fontes de dados diferentes na construção de um indicador (Caseiro; Azevedo, 2018).
} 


$$
\begin{gathered}
\text { População a ser } \\
\text { incluída na graduação }
\end{gathered} \quad=0,5 * \begin{gathered}
\text { População de } \\
18 \text { a } 24 \text { anos }
\end{gathered}-\begin{gathered}
\text { População que } \\
\text { frequenta a graduação }
\end{gathered}
$$

Utilizando os dados da Pnad Contínua, é possível observar a evolução dessa estimativa para o período de 2012 a 2017 (Gráfico 1). Em 2017, faltava aumentar o número de alunos na educação superior em 3,51 milhões para alcançar o objetivo da TBM - assumindo que essa população permaneceria do mesmo tamanho. Ou seja, os cursos brasileiros de graduação devem estar aptos a atender 11,42 milhões de alunos em 2024 (dado obtido pela soma das duas linhas do Gráfico 1). ${ }^{3}$

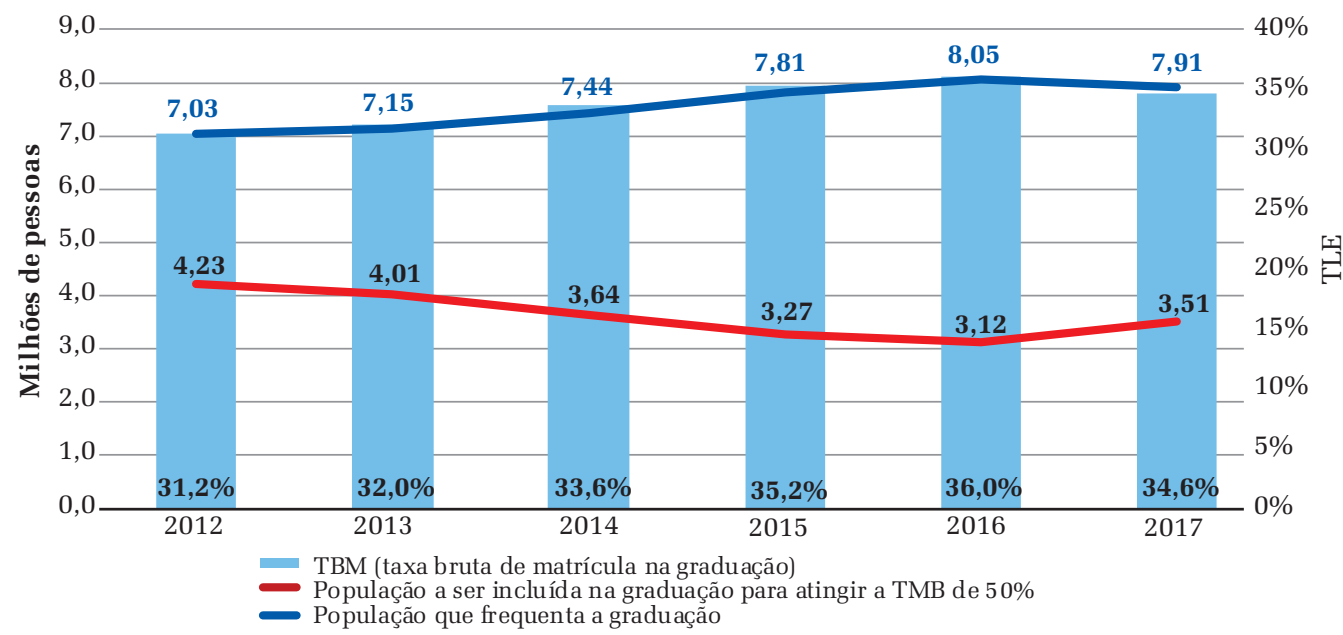

\section{GRÁFICO 1}

\section{POPULAÇÃO A SER INCLUÍDA NA GRADUAÇÃO - BRASIL - 2012-2017} (EM MILHÕES DE PESSOAS)

Fonte: Elaboração própria com base em dados da Pnad Contínua - 2º trimestre (2012-2017)/IBGE.

De modo semelhante, a população de 18 a 24 anos a ser incluída na graduação para atingir a Meta 12 pode ser calculada com base nos parâmetros fornecidos pelo texto do PNE e nos dados disponíveis na Pnad Contínua. Em termos práticos, elevar a taxa líquida de escolarização a 33\% equivale a dizer que um terço dos jovens da faixa etária de referência precisará ter acesso à educação superior. Essa estimativa, portanto, pode ser obtida pela Equação 2:

$$
\underset{\text { População de } 18 \text { a } 24 \text { anos }}{\text { a ser incluída na graduação }}=0,33 \text { * População de } \begin{gathered}
\text { População de } 18 \text { a } 24 \\
18 \text { a } 24 \text { anos }
\end{gathered} \quad \begin{gathered}
\text { anos que frequenta ou já } \\
\text { concluiu a graduação }
\end{gathered}
$$

\footnotetext{
3 Caso fosse considerada a informação da projeção demográfica atualizada do IBGE, a população total que precisaria estar matriculada na graduação em 2024 - 50\% da população projetada para a faixa etária de 18 a 24 anos - seria de 11,06 milhões (IBGE, 2018). Nota-se que a estimativa dada pela Pnad Contínua é mais conservadora.
} 
A população de 18 a 24 anos a ser incluída na graduação para atingir a Meta 12 do PNE é apresentada no Gráfico 2. Em 2017, 5,29 milhões de jovens nessa faixa etária, ou $23,2 \%$ do total, tiveram acesso aos cursos de graduação. Para alcançar a meta de 33\% da taxa líquida até 2024, faltaria incluir 2,24 milhões de jovens de 18 a 24 anos nos cursos de graduação. O total de jovens dessa faixa etária que precisará ter acesso ao ensino superior em 2024 é de 7.53 milhões (valor obtido pela soma das duas linhas).

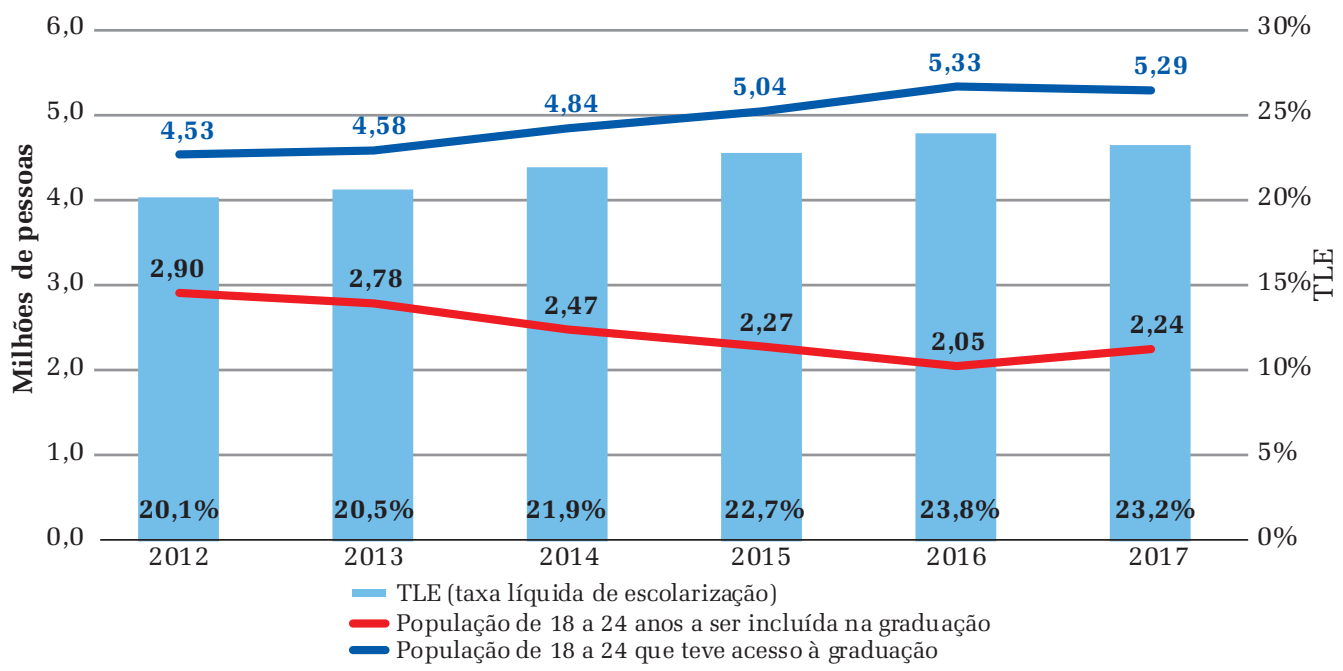

GRÁFICO 2

POPULAÇÃO DE 18 A 24 ANOS A SER INCLUÍDA NA GRADUAÇÃO - BRASIL - 2012-2017 (EM MILHÕES DE PESSOAS)

Fonte: Elaboração própria com base em dados da Pnad Contínua - $2^{\circ}$ trimestre (2012-2017)/IBGE.

Essas duas estimativas apresentadas trazem implícita a ideia de que não haverá uma diminuição do acesso à graduação. Caso isso ocorra, a população que precisará ser incluída para cumprir as metas do PNE aumentará, de modo a atingir sempre 11,42 milhões no total e 7,53 milhões de pessoas de 18 a 24 anos. Se a população de 18 a 24 anos continuar a apresentar a tendência de diminuição, esses quantitativos podem reduzir marginalmente.

Uma primeira questão que se coloca aos gestores públicos diz respeito a quantas matrículas serão necessárias para garantir a inclusão de 11,42 milhões de alunos na educação superior. Entre 2012 e 2016, o número de matrículas ativas reportadas pelos Censos da Educação Superior (CES) foi em média 2,0\% superior ao número de alunos reportados pelo segundo trimestre da Pnad Contínua (Gráfico B1, Apêndice B). ${ }^{4}$ Se essa proporção for mantida, será preciso atingir 11,65 milhões de matrículas em 2024 para incluir 11,42 milhões de alunos dos cursos de graduação.

\footnotetext{
${ }^{4}$ Se nos indicadores de população a ser incluída, objeto das seções 2.1 e 2.2, foram utilizadas as informações obtidas por meio da Pnad Contínua, para o indicador de expansão de matrículas a fonte terá que ser, necessariamente, os CES, uma vez que a Pnad não informa o número de matrículas.
} 
A segunda questão diz respeito a qual deve ser o tamanho da expansão da graduação no segmento público. No monitoramento do PNE, o ano de referência inicial, com base no qual deve ser assegurada a expansão para $40 \%$ das novas matrículas no segmento público até 2024, é o ano de 2012. ${ }^{5}$ No ano base de 2012 havia um total de 7,04 milhões de matrículas nos cursos de graduação, nos segmentos público e privado. Portanto, para chegar a 11,65 milhões de matrículas necessárias para o cumprimento da meta da TBM é preciso uma expansão de 4,61 milhões de matrículas entre 2012 e 2024. Visto que $40 \%$ da expansão deve ocorrer no segmento público, isso indica que tal segmento precisaria ampliar seu quantitativo de matrículas em 1,84 milhão, atingindo um total de 3,74 milhões de matrículas na graduação em 2024. A evolução da expansão necessária do segmento público, de 2012 a 2016, é apresentada no Gráfico 3.

Observa-se, no Gráfico 3, que o segmento público pouco avançou em número de matrículas entre 2012 e 2016. Obteve um crescimento de apenas 92,7 mil matrículas nesse intervalo de quatro anos, ou apenas 5,0\% da expansão que será necessária até o ano de 2024 para alcançar a meta estabelecida no PNE, caso o objetivo da taxa bruta também seja cumprido. Ao final de 2016, ainda restava ao segmento público ampliar 1,75 milhão de matrículas até 2024. Ou seja, precisaria criar, em média, 218,8 mil matrículas por ano, nesse período, enquanto o ritmo médio de crescimento observado nos últimos quatro anos foi de apenas 23,2 mil matrículas por ano. Para fazer sua parte no cumprimento do PNE, o segmento público de educação superior precisa aumentar em nove vezes o ritmo de expansão observado nos últimos quatro anos.

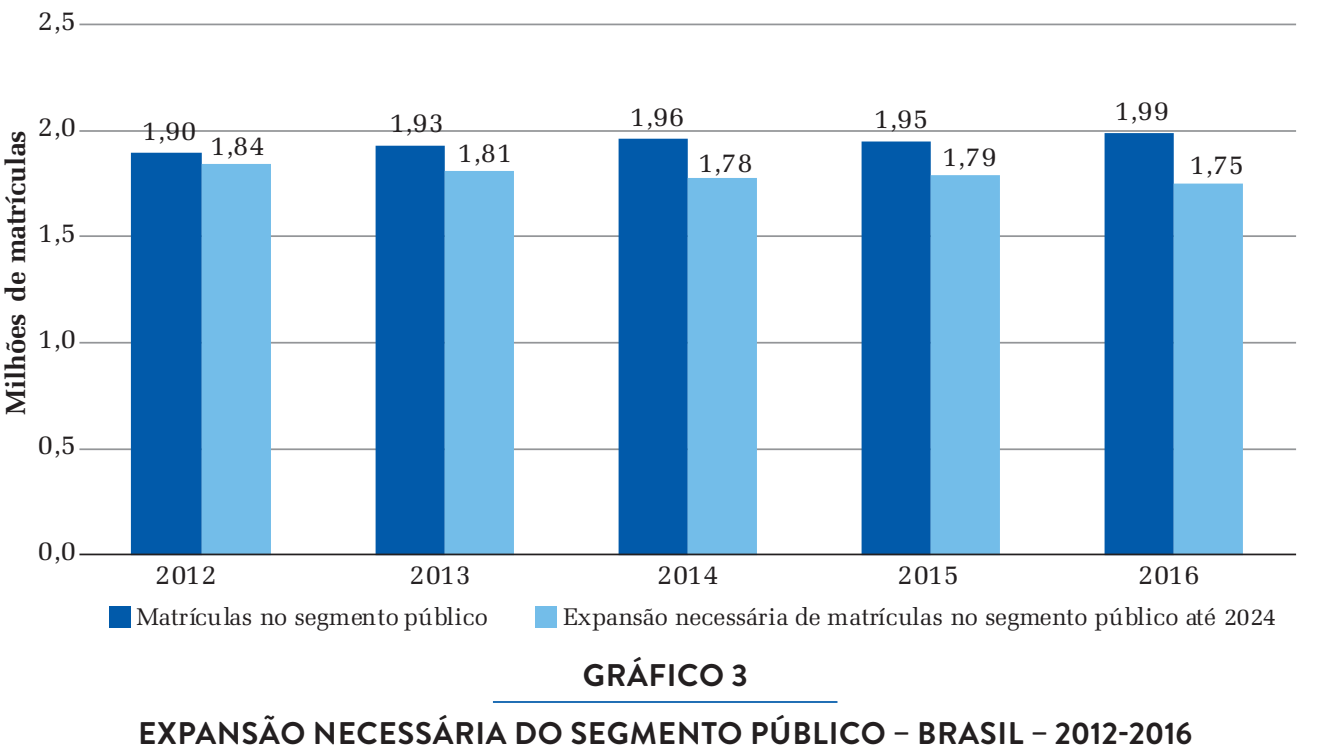

Fonte: Elaboração própria com base em dados do Censo da Educação Superior (2012-2016) e da Pnad Contínua $2^{\circ}$ trimestre (2017)/IBGE.

\footnotetext{
Segundo o art. $4^{\circ}$ do PNE, as metas previstas a serem monitoradas "deverão ter como referência a Pesquisa Nacional por Amostra de Domicílios - PNAD, o censo demográfico e os censos nacionais da educação básica e superior mais atualizados, disponíveis na data da publicação desta Lei” (Brasil, 2014). No caso do CES, o levantamento mais recente disponível em 25 de junho de 2014, era o de 2012.
} 


\section{O QUE FAZER PARA CUMPRIR A META 12 DO PNE?}

As três estimativas produzidas acima revelam que o País se encontra muito distante de cumprir os objetivos estabelecidos pela Meta 12 do PNE. Falta incluir, no mínimo, 3,51 milhões de pessoas na graduação (sendo que destas 2,24 milhões de jovens de 18 a 24 anos) e o segmento público precisa criar 1,75 milhão de matrículas. Em um contexto político e econômico marcado pela contenção de gastos públicos, é pouco provável garantir essa expansão apenas com a criação de novas vagas. Não obstante, o próprio PNE, por meio de suas estratégias, oferece algumas alternativas para ampliar a inclusão da população na educação superior. A Estratégia 12.1 estabelece uma diretriz geral para otimizar a capacidade instalada nas IES públicas. As Estratégias 12.3 e 12.17 trazem três caminhos pelos quais esse melhor aproveitamento dos recursos existentes nas IES públicas pode ocorrer. Esses caminhos são:

1. Reduzir a ociosidade de vagas na educação superior pública.

2. Elevar a taxa de conclusão média dos cursos de graduação presenciais para $90 \%$.

3. Ofertar, no mínimo, um terço das vagas em cursos noturnos.

As estimativas apresentadas nesta seção dizem respeito, portanto, às três estratégias listadas acima para otimizar a capacidade instalada nas IES públicas. Com base nesses exercícios, espera-se subsidiar os esforços da ação estatal para que seja possível aproximar o segmento público de educação superior dos objetivos estabelecidos pela Meta 12 do PNE.

\subsection{REDUZIR A OCIOSIDADE DE VAGAS NA EDUCAÇÃO SUPERIOR}

A possibilidade de ampliação das matrículas na educação superior por meio da otimização dos recursos existentes começa já no processo de seleção dos candidatos ao ingresso. Não é fato novo que há um elevado percentual de vagas ociosas na educação superior brasileira (Souza, 2013; Almeida, 2015). Essa ociosidade ocorre apesar de o número de candidatos inscritos nos processos seletivos superar, normalmente, o número de vagas existentes, ao menos nas IES públicas.

Há dois grandes tipos de oferta de vagas nos cursos de graduação, de acordo com a nomenclatura utilizada no CES. Há, primeiramente, as "vagas novas”, que são ofertadas por meio dos processos seletivos tradicionais (vestibular, Exame Nacional do Ensino Médio - Enem, avaliação seriada, seleção simplificada), para ingresso no início do curso, em cada turno de funcionamento. O segundo tipo são as "vagas remanescentes", que no manual de preenchimento do CES têm a seguinte definição: 


\begin{abstract}
Vagas remanescentes: são vagas de anos anteriores que nunca foram ocupadas ou que foram liberadas por diversos motivos: óbito, não cumprimento de desempenho mínimo (jubilamento), desistência, transferência interna (transferência entre cursos da IES), transferência externa (transferências de outras IES). A forma de ingresso nessas vagas define-se como "processos seletivos para vagas remanescentes" (transferência externa, transferência interna, portador de curso superior e reingresso) (Brasil. Inep, 2015b, p. 25).
\end{abstract}

Convém separar esses dois tipos de ociosidade das vagas em nossa análise, pois elas têm causas distintas, e, desse modo, requerem políticas distintas. A ociosidade de vagas novas pode ter como causas prováveis a existência de barreiras de ingresso, ou o desinteresse prévio da população por um curso, oferecido em determinada região. As barreiras de ingresso podem ser múltiplas, como a não conclusão do ensino médio, a existência de processos seletivos muito rigorosos, distância da moradia em relação ao curso almejado e dificuldades socioeconômicas, como a impossibilidade de conciliar estudo e trabalho ou a falta de renda para pagar as mensalidades, no caso dos cursos pagos. Muitas dessas barreiras também podem ser comuns ao ingresso nas vagas remanescentes, mas nelas o ingresso pode ser ainda mais difícil pela necessidade adicional de dominar os conteúdos das disciplinas dos primeiros anos dos cursos desejados. Essa barreira adicional pode ajudar a explicar a baixa concorrência e o baixo preenchimento das vagas remanescentes.

O Gráfico 4 apresenta as relações candidato/vaga e vaga/ingressante nos cursos de graduação no segmento público e no segmento privado no ano de 2016, considerando-se os dois tipos de oferta de vagas: novas e remanescentes. Nos cursos públicos, há, em média, apenas 0,9 candidato por vaga remanescente, e o número de ingressantes é quatro vezes inferior ao número de vagas dessa modalidade. Nos cursos privados a situação é ainda pior, com 0,5 candidato por vaga remanescente e com a existência de oito vezes mais vagas remanescentes do que o número de ingressantes dessa modalidade.

Embora o acesso às vagas remanescentes seja um importante instrumento para a mobilidade dos estudantes e para que cada curso otimize sua capacidade instalada, atraindo novos alunos, no agregado, elas pouco alteram a situação de acesso da população aos cursos de graduação. No caso das transferências entre cursos, por exemplo, o estudante pode melhorar a sua situação de ensino e aprendizagem do ponto de vista individual ao optar por um curso que melhor se adeque às suas aspirações profissionais. Entretanto, quando ocorre uma transferência entre cursos, uma vaga remanescente é criada, enquanto outra é preenchida. Por isso, em uma perspectiva do sistema de ensino superior brasileiro, este artigo enfoca as causas das vagas remanescentes: a existência de ociosidade de vagas iniciais e os elevados índices de desistência dos cursos. Assim, se essas duas questões forem tratadas, o problema do alto número de vagas remanescentes será solucionado. Por isso, o foco desta seção 
será a ociosidade de vagas iniciais, enquanto a questão da desistência dos cursos será tratada na seção seguinte.

Há, segundo o CES, outro tipo de oferta de vagas, denominado "vagas para programas especiais", tais como o Plano Nacional de Formação de Professores da Educação Básica (Parfor), o Programa Nacional de Educação na Reforma Agrária (Pronera) e o Programa de Apoio à Formação Superior em Licenciatura em Educação do Campo (Procampo). Essas vagas correspondem a uma parcela muito pequena do total de vagas. Uma vez que a quase totalidade dos alunos desses programas ingressam por meio de processos seletivos, essas vagas serão computadas também como vagas iniciais, junto com as vagas novas.

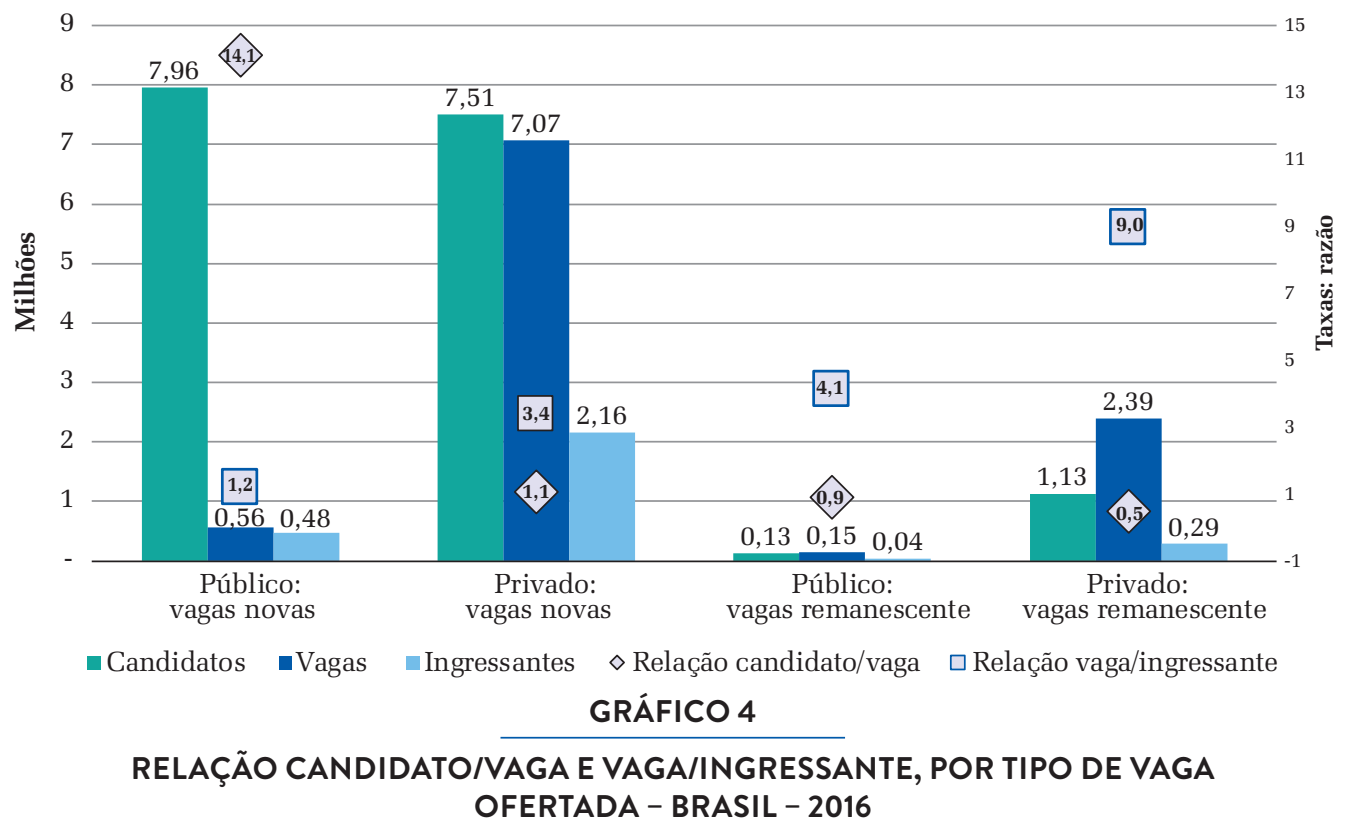

Fonte: Elaboração própria com base em dados do Censo da Educação Superior (2016).

\subsubsection{Taxa de ociosidade em vagas iniciais}

A taxa de ociosidade é um importante indicador da eficiência dos sistemas de seleção e ingresso, bem como da atratividade dos cursos de graduação, e sua redução está prevista na Estratégia 12.17 do PNE. A taxa de ociosidade pode ser calculada conforme a Equação 3:

$$
\begin{gathered}
\text { Taxa de ociosidade } \\
\text { em vagas iniciais }
\end{gathered}=\frac{\begin{array}{c}
\text { Vagas iniciais } \\
\text { ofertadas }
\end{array}-\begin{array}{c}
\text { Ingressos em } \\
\text { vagas iniciais }
\end{array}}{\begin{array}{c}
\text { Vagas iniciais } \\
\text { ofertadas }
\end{array}}
$$


Neste trabalho, a taxa de ociosidade foi calculada por curso, com base nos microdados do CES de 2016. Para esse cálculo foi adotado um procedimento de tratamento dos dados. Observou-se que havia cursos em que o número de ingressantes em vagas iniciais excedia o número de vagas iniciais ofertadas. Nesses casos, o número de ingressantes em vagas iniciais foi considerado como sendo idêntico ao número de vagas iniciais ofertadas. Caso esse procedimento não fosse adotado, esses cursos teriam taxa de ociosidade negativa, o que enviesaria as análises.

Observa-se, no Gráfico 4, que o número de candidatos inscritos superou substancialmente o número de vagas ofertadas nos processos seletivos para as vagas iniciais das IES públicas em 2016. Considerados no agregado, os processos seletivos para vagas iniciais das IES privadas têm, aproximadamente, um candidato por vaga. Não obstante, tanto nas IES públicas quanto nas IES privadas, o número de novos ingressantes nos cursos é menor do que o número de vagas.

Em 2016, as IES públicas ofertaram 564.685 vagas iniciais, quantidade 17,6\% superior ao número de ingressantes, totalizando 84.656 vagas ociosas e uma taxa de ociosidade total de $15,0 \%$. As IES privadas, por sua vez, ofertaram 7,07 milhões de vagas iniciais em 2016 e receberam 7,51 milhões de inscrições de candidatos para ocupar essas vagas. Não obstante, o número de ingressantes foi de apenas 2,16 milhões, totalizando 4,91 milhões de vagas ociosas e uma taxa de ociosidade de 69,5\%.

É difícil compreender o elevado percentual de ociosidade de vagas no ensino superior brasileiro, em especial no segmento público, em virtude de o número de candidatos inscritos superar o número de vagas. Assim, é necessário um panorama por cursos, de modo a identificar os fatores associados à ociosidade. A Tabela 2 apresenta as taxas de ociosidade das 15 áreas de cursos públicos que mais ofertaram vagas em 2016. Esses dados revelam que a elevada taxa de candidatos por vaga e a ociosidade de vagas são onipresentes no segmento público nas mais variadas áreas de conhecimento. Os cursos de medicina, considerados no agregado, são quase uma exceção (com mais de 63 candidatos por vaga nova), ao apresentarem a menor taxa de ociosidade, de apenas 4,0\%. Ainda assim, a ociosidade de vagas está presente.

Entre os cursos públicos de graduação com maior quantidade total de vagas ociosas, destacam-se, negativamente, os cursos de formação de professores para educação básica. É relevante lembrar que a oferta de cursos de formação de professores, sobretudo nas áreas de ciências e matemática, é priorizada pelas estratégias da Meta 12 do PNE. ${ }^{6}$ Considerando-se apenas a modalidade de ensino presencial, os cursos de

\footnotetext{
6 Estratégia 12.4: "fomentar a oferta de educação superior pública e gratuita prioritariamente para a formação de professores e professoras para a educação básica, sobretudo nas áreas de ciências e matemática [...]" (Brasil, 2014); e Estratégia 12.14: "mapear a demanda e fomentar a oferta de formação de pessoal de nível superior, destacadamente a que se refere à formação nas áreas de ciências e matemática, considerando as necessidades do desenvolvimento do País, a inovação tecnológica e a melhoria da qualidade da educação básica” (Brasil, 2014).
} 
licenciatura em matemática apresentam a maior quantidade de vagas iniciais ociosas (3.148) e a maior taxa de ociosidade em vagas iniciais (19,5\%). Isso ocorre apesar de o número de candidatos inscritos nos processos seletivos para cursos presenciais de licenciatura em matemática ser oito vezes superior ao número de vagas ofertadas. $\mathrm{O}$ elevado número de candidatos inscritos por vagas e de vagas ociosas é regra nos mais diversos cursos públicos de formação de professores.

TABELA 2

OCIOSIDADE NOS 15 CURSOS PÚBLICOS COM MAIOR OFERTA DE VAGAS INICIAIS - BRASIL

\begin{tabular}{|c|c|c|c|c|c|c|}
\hline Modalidade & \multicolumn{3}{|c|}{ Presencial } & \multicolumn{3}{|c|}{ EaD } \\
\hline Curso & Vagas & $\begin{array}{l}\text { Candidato } \\
\text { /vaga }\end{array}$ & $\begin{array}{c}\text { Taxa de } \\
\text { ociosidade }\end{array}$ & Vagas & $\begin{array}{c}\text { Candidato } \\
\text { /vaga }\end{array}$ & $\begin{array}{c}\text { Taxa de } \\
\text { ociosidade }\end{array}$ \\
\hline Pedagogia & 23.755 & 13,3 & $17,4 \%$ & 4.978 & 2,5 & $18,3 \%$ \\
\hline Administração & 21.958 & 17,7 & $17,0 \%$ & 1.922 & 2 & $17,7 \%$ \\
\hline $\begin{array}{l}\text { Matemática } \\
\text { (licenciatura) }\end{array}$ & 16.125 & 8,1 & $19,5 \%$ & 3.891 & 1,9 & $54,3 \%$ \\
\hline Direito & 19.897 & 23,1 & $10,2 \%$ & - & - & - \\
\hline Biologia (licenciatura) & 13.006 & 12,1 & $15,7 \%$ & 2.892 & 1,8 & $41,0 \%$ \\
\hline Ciências contábeis & 12.042 & 11,8 & $14,0 \%$ & 358 & 1,6 & $47,5 \%$ \\
\hline $\begin{array}{l}\text { Português } \\
\text { (licenciatura) }\end{array}$ & 10.323 & 9,7 & $16,0 \%$ & 1.674 & 3,1 & $26,2 \%$ \\
\hline Agronomia & 11.738 & 13 & $7,6 \%$ & - & - & - \\
\hline Engenharia civil & 11.520 & 17,8 & $14,2 \%$ & - & - & - \\
\hline Química (licenciatura) & 9.874 & 9,9 & $17,5 \%$ & 1.366 & 0,8 & $59,7 \%$ \\
\hline $\begin{array}{l}\text { Análise e desenvolvi- } \\
\text { mento de sistemas }\end{array}$ & 10.068 & 12,1 & $8,2 \%$ & 1.058 & 3,6 & $11,6 \%$ \\
\hline História (licenciatura) & 9.841 & 10,3 & $18,8 \%$ & 1.150 & 3,3 & $43,3 \%$ \\
\hline Medicina & 10.354 & 62,8 & $4,0 \%$ & - & - & - \\
\hline Física (licenciatura) & 8.596 & 8,6 & $17,7 \%$ & 1.399 & 0,9 & $48,3 \%$ \\
\hline Enfermagem & 9.195 & 23,1 & $16,7 \%$ & - & - & - \\
\hline
\end{tabular}

Fonte: Elaboração própria com base em dados do Censo da Educação Superior (2016).

Desse modo, há uma aparente generalidade das vagas ociosas, quando se consideram as taxas médias agregadas por áreas de curso. O Gráfico 5 oferece uma perspectiva distinta, ao considerar a distribuição do número de cursos por faixas da taxa de ociosidade. Constata-se que, na educação superior pública, 36,6\% dos cursos presenciais não tinham nenhuma vaga nova ociosa em 2016, e mais de dois terços dos cursos tinham ociosidade menor do que 10\%. Ou seja, um terço dos cursos públicos presenciais apresenta uma taxa de ociosidade mais alta, elevando as médias 
agregadas. No segmento privado, cerca de $60 \%$ dos cursos presenciais possuem taxa de ociosidade das vagas iniciais ofertadas/autorizadas ${ }^{7}$ superior a $50 \%$.

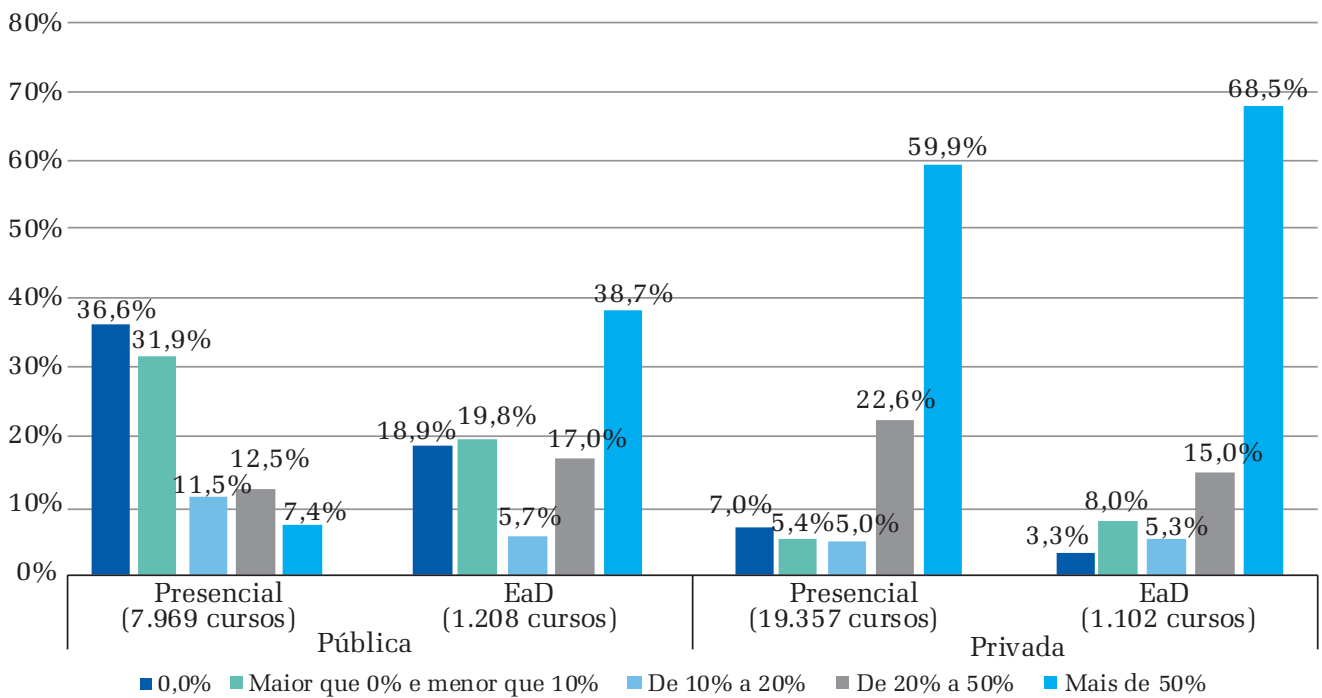

GRÁFICO 5

\section{TAXA DE OCIOSIDADE, POR SEGMENTO E MODALIDADE DE ENSINO - BRASIL - 2016 (EM \% DE CURSOS DE CADA SEGMENTOIMODALIDADE, POR FAIXAS DA TAXA DE OCIOSIDADE)}

Fonte: Elaboração própria com base em dados do Censo da Educação Superior (2016).

Existe também grande heterogeneidade no universo dos cursos públicos presenciais (Gráfico 6). Nos institutos federais, mais da metade dos cursos não apresentou nenhuma ociosidade de vagas. Nas universidades federais apenas um quarto dos cursos possui ociosidade de vagas iniciais superior a 10\%. Nas IES estaduais, um terço dos cursos têm taxa de ociosidade superior a esse patamar. Dessa perspectiva de análise, o destaque negativo é das IES municipais, em que cerca de $85 \%$ dos cursos apresentam ociosidade superior a 10\% e quase metade dos cursos têm ociosidade superior a 50\%. Essa elevada ociosidade de vagas nas IES municipais pode ter, ao menos, duas causas complementares. Por um lado, um possível menor prestígio relativo dessas instituições, comparadas às IES federais e estaduais. Por outro, o fato

\footnotetext{
7 Faltam pesquisas que procurem verificar se os cursos privados ofertam de fato todas as vagas que declaram no CES. Souza (2013) e Almeida (2015) trabalham com a hipótese de que muitos cursos privados declararam a quantidade de vagas autorizadas e não efetivamente ofertadas. Apesar disso, o manual de preenchimento da coleta de dados do CES é claro ao afirmar que os responsáveis legais devem informar as vagas efetivamente ofertadas. De todo modo, uma vez que o interesse deste trabalho é considerar a capacidade de oferta das IES, as vagas autorizadas podem ser tratadas como capacidade existente, independente da oferta efetiva ou não, uma vez que a autorização é reconhecida por meio da demonstração da capacidade de receber ingressantes para todas as vagas solicitadas. Esse mesmo argumento foi utilizado nas análises de Souza (2013) e Almeida (2015).
} 
de a maioria dos cursos nas IES municipais requerer o pagamento de mensalidades dos estudantes. ${ }^{8}$

A análise das taxas de ociosidade apresentadas até aqui permite que sejam elencados dois possíveis fatores associados à elevada taxa de escolaridade: o pagamento de mensalidades e os diferenciais de prestígio dos cursos e instituições. Pesquisas adicionais são necessárias, contudo, para testar essas hipóteses. Elas relacionam o nível de ociosidade dos cursos a um provável maior interesse dos candidatos à educação superior por cursos gratuitos e de maior prestígio.

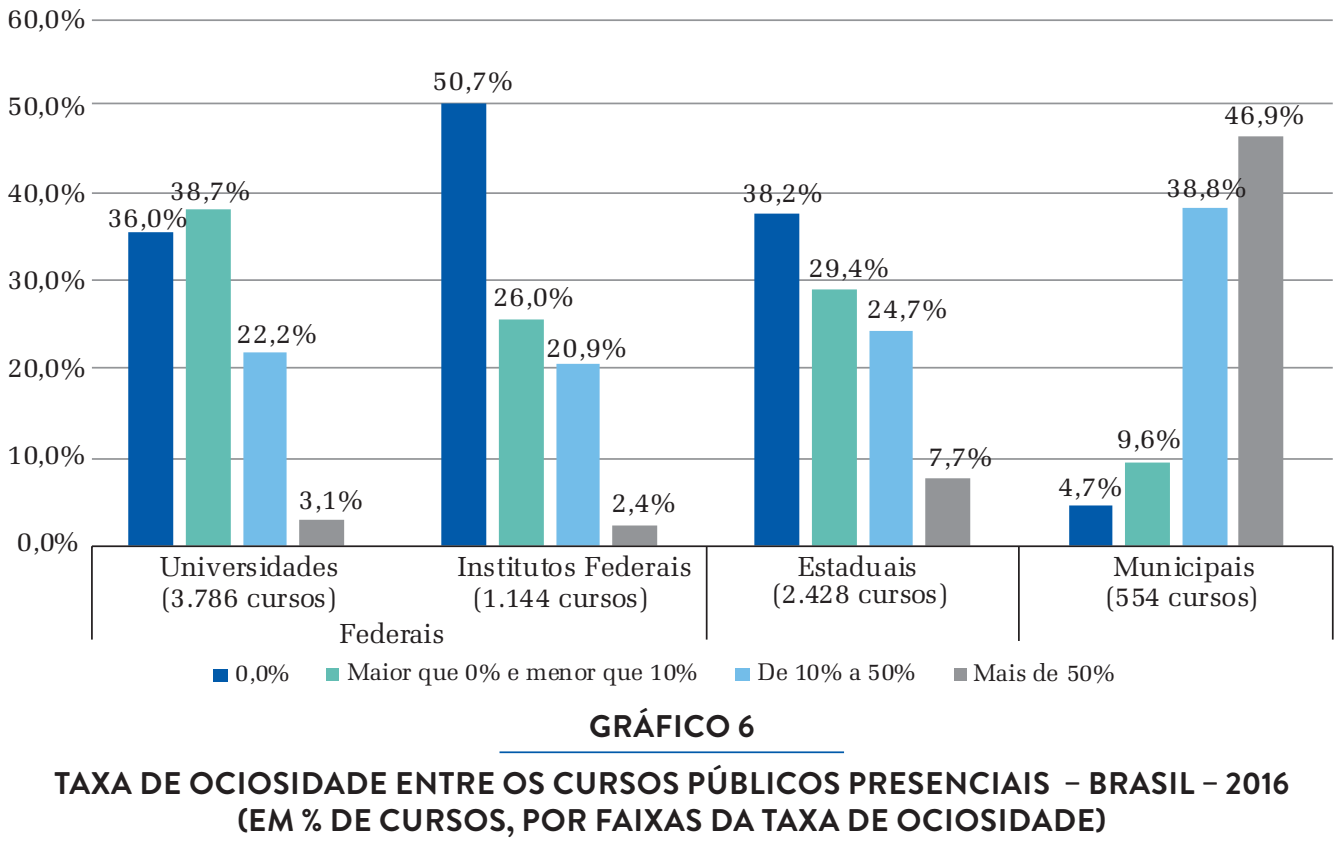

Fonte: Elaboração própria com base em dados do Censo da Educação Superior (2016).

Não obstante, é possível observar a existência de ociosidade de vagas mesmo em cursos gratuitos, em instituições de prestígio e com elevado número de candidatos por vagas. No Gráfico 7, observa-se como são associadas a taxa de ociosidade e a relação candidato/vaga em cursos de educação superior públicos de universidades federais e estaduais, que são, no geral, de alta demanda e considerados de elevado prestígio. Nota-se que, embora haja uma associação positiva entre a relação candidato/vaga e a ociosidade, a última está presente mesmo em cursos de elevada procura, com mais de 20 candidatos por vaga. Dentro desse grupo de cursos de alta demanda, 1.059 cursos $(58,8 \%)$ apresentam alguma ociosidade de vagas, 312 cursos $(17,3 \%)$ apresentam ociosidade de vagas iniciais superior a $10 \%$ e 65 cursos $(3,6 \%)$ apresentam ociosidade de vagas superior a 30\%. Entre esses 65 cursos públicos, gratuitos e presenciais,

\footnotetext{
8 Segundo os dados do Censo da Educação Superior 2016, 82,7\% dos cursos presenciais das IES municipais eram pagos.
} 
de elevada ociosidade e alta demanda, encontram-se 17 cursos de formação de professores, três cursos de direito, três de engenharia, dois de medicina, entre outros. Ou seja, o problema da ociosidade de vagas é mais complexo do que a falta de candidatos interessados, visto que a ociosidade está presente mesmo em cursos de elevada demanda e prestígio. Por outro lado, há 715 cursos de baixa demanda, com menos de cinco candidatos por vaga, que conseguiram preencher todas as vagas iniciais ofertadas. A correlação entre ambas as variáveis existe, mas é apenas de -0,15, podendo ser considerada fraca (Tabela A1, Apêndice A).

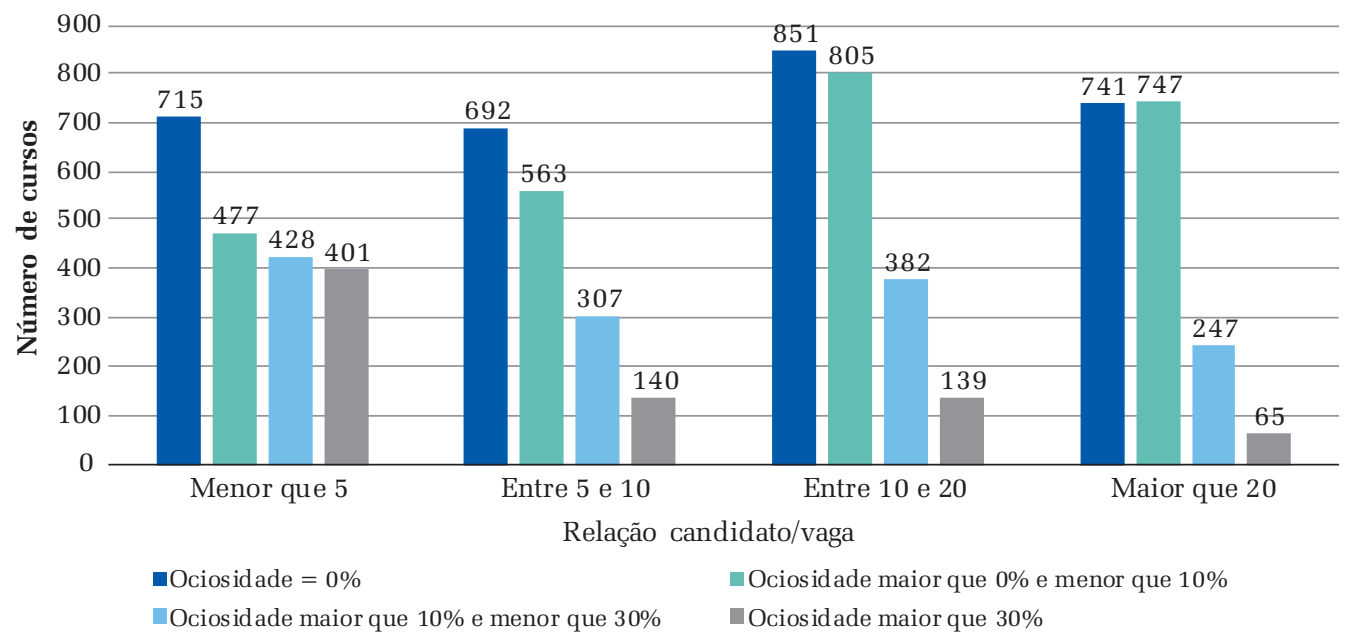

GRÁFICO 7

\section{RELAÇÃO ENTRE OCIOSIDADE DE VAGAS E DEMANDA DE CANDIDATOS INSCRITOS EM CURSOS PRESENCIAIS DE IES FEDERAIS E ESTADUAIS, POR NÚMERO DE CURSOS EM CADA FAIXA DA TAXA DE OCIOSIDADE E DA RELAÇÃO CANDIDATO/VAGA - BRASIL - 2016}

Fonte: Elaboração própria com base em dados do Censo da Educação Superior (2016).

Por essas evidências preliminares é possível levantar a hipótese de que há um problema de eficiência alocativa nos processos seletivos vigentes. A candidatura a um curso não significa que essa seja a primeira opção do estudante. Um aluno com melhores notas pode ser aprovado em processos seletivos de vários cursos e, ao final, provavelmente, optará por apenas um. Os alunos com desempenhos inferiores nos processos seletivos podem não ser aprovados em nenhum dos cursos que desejam. Nesse sentido, a eficiência alocativa dos processos seletivos individuais pode ser uma barreira à entrada no ensino superior. Assim, iniciativas de processos seletivos unificados nacionalmente, como o caso do Sistema de Seleção Unificada (Sisu), podem contribuir para diminuir a ociosidade de vagas iniciais. ${ }^{9}$ Essa hipótese

\footnotetext{
9 Embora existam pesquisas e relatos de gestores universitários de que o Sisu pode também contribuir para o aumento da desistência de curso, em virtude da mobilidade conferida aos alunos (Barbosa et al., 2017).
} 
precisa ser ainda mais bem investigada, mas é interessante notar que a rede federal de educação superior, que aderiu em maior proporção ao Sisu, conta com o maior percentual de cursos sem vagas ociosas (Gráfico 6). Uma análise de variância indica que, no segmento público, as diferenças entre as IES explicam dois terços da variância da taxa de ociosidade média, importando mais do que as diferenças entre os cursos individuais e as áreas de conhecimento (Gráfico B2, Apêndice B). Uma vez que os processos seletivos são normalmente definidos pelas instituições, inclusive com a adesão ou não ao Sisu, essa informação reforça a hipótese de a taxa de ociosidade estar também relacionada ao formato dos processos seletivos adotados, além do prestígio de cada instituição.

Uma vez que o universo de cursos é muito amplo e as causas da ociosidade podem ser diversas, inclusive sendo distintas conforme cada curso, não há como, dentro do escopo deste artigo, esgotar a análise da taxa de ociosidade dos cursos de graduação. Duas conclusões importantes, entretanto, decorrem da presente análise. A primeira é que há uma grande variabilidade e generalidade do fenômeno nos mais diversos tipos de cursos e IES. A segunda conclusão indica que é possível almejar uma taxa de ociosidade próxima a zero nos cursos públicos presenciais, uma vez que $50,7 \%$ dos cursos ofertados pelos institutos federais têm ociosidade de vagas iniciais igual a zero e 76,7\% deles têm taxa de ociosidade de vagas iniciais inferior a $10 \%$. No que tange ao monitoramento do PNE, a análise aqui apresentada pode oferecer contribuições para pesquisas futuras que visem o cumprimento da Estratégia 12.17, em que está prevista a criação de mecanismos para o preenchimento de vagas ociosas no segmento público. Além disso, sublinha-se que essa estratégia se encontra diretamente relacionada aos objetivos centrais da Meta 12, que são: o aumento das matrículas públicas e da inclusão da população na educação superior.

\subsection{AUMENTAR AS TAXAS DE CONCLUSÃO DO ENSINO SUPERIOR}

A segunda possibilidade de ampliação das matrículas na graduação, por meio da otimização dos recursos existentes, diz respeito à elevação da taxa de conclusão dos cursos. Ações nesse sentido são previstas pela Estratégia 12.3 e 13.8 do PNE, que determinam a elevação da taxa de conclusão dos cursos de graduação presenciais nas universidades públicas para 90\% e nas IES privadas para 75\%.

Neste trabalho, calculou-se as taxas de conclusão segundo o curso de origem para a coorte de ingressantes no sistema em 2010. Esse cálculo foi realizado por meio do acompanhamento longitudinal da trajetória dessa coorte de ingressantes entre os anos de 2010 e 2016, totalizando um período de sete anos. Para realizar essas estimativas, foram utilizados os dados do CES. Segundo as informações disponíveis no CES de 2010, 99,7\% dos cursos de graduação possuíam prazos mínimos de integralização menor que sete anos. Apesar disso, foi identificado um percentual não desprezível 
de ingressantes em 2010 que permaneceram com situação indefinida em seus cursos de origem ao final de 2016. Cerca de 5\% dos alunos não concluíram nem desistiram formalmente de seus cursos, permanecendo, no último ano da análise, matriculados.

As elevadas taxas de desistência dos cursos de graduação brasileiros têm recebido maior atenção da literatura acadêmica do que o tema da ociosidade de vagas (Andifes; Abruem; Brasil. MEC, 1996; Braga; Miranda-Pinto; Cardeal, 1997; Ribeiro, 2005; Cardoso, 2008; Silva Filho et al., 2007; Baggi; Lopes, 2011; Morosini et al., 2012; Rabelo; Cavenaghi, 2016). Entretanto, até muito recentemente, não havia nenhuma estimativa oficial para as taxas de desistência e de conclusão dos cursos de graduação em todo o Brasil. Os trabalhos existentes procuravam estimar taxas de desistência anuais e taxas de conclusão aproximadas em todo sistema, com base nas sinopses do CES (Silva Filho, 2007) ou focavam na análise da evasão de cursos ou de IES específicas (Andifes; Abruem; Brasil. MEC, 1996; Miranda-Pinto; Cardeal, 1997; Cunha; Tunes; Silva, 2001; Ribeiro, 2005; Cardoso, 2008).

No ano de 2017, a ausência de estimativas oficiais para as taxas de desistência e conclusão foi superada com a introdução, pela Diretoria de Estatísticas Educacionais do Inep (Deed/Inep), de uma metodologia para o acompanhamento da trajetória dos alunos de todos os cursos de graduação no Brasil ao longo dos diversos CES (Brasil. Inep, 2017a, 2017b). A implementação dessa metodologia de análise longitudinal possibilitou a construção de indicadores de fluxo nos cursos de graduação e, desse modo, das primeiras estimativas oficiais para as taxas de desistência e conclusão nos cursos de graduação, tomando como ponto de partida a coorte de alunos ingressantes em 2010. Essa coorte de alunos foi acompanhada durante cinco anos, até 2014. A unidade de análise para o acompanhamento da trajetória dos estudantes foram os cursos de origem nos quais esses estudantes estavam matriculados no ano de 2010. Trata-se, portanto, de um estudo da trajetória dos estudantes por curso. Um estudante que trocou de curso e concluiu um diferente daquele no qual havia ingressado em 2010 é considerado como desistente do curso de origem. Nesse caso, ele será considerado concluinte apenas quando a coorte de seu novo ingresso for analisada. Mas até o momento apenas a coorte de ingressantes de 2010 foi objeto da análise.

Com base nessa nova metodologia do Inep, ao contrário do que acontece com a maior parte da literatura acadêmica, foi utilizado o conceito de desistência do curso ao invés do conceito de evasão. O conceito de evasão é polissêmico, podendo referir-se à ruptura do vínculo do aluno com o curso - evasão do curso -, à ruptura do vínculo com a instituição - evasão da instituição -, ou à desistência do aluno de concluir qualquer curso de graduação - evasão do sistema - (Andifes; Abruem; Brasil. MEC, 1996). Para evitar ambiguidades, preferiu-se adotar o conceito de desistência do curso. Isso significa que as taxas de desistência reportadas são relativas a alunos que romperam seu vínculo de matrícula com o curso, podendo, ou não, ter concluído outro curso de graduação. 
O estudo do Inep apresentou as taxas de desistência para a coorte ingressante em 2010 até o ano de 2014 (Brasil. Inep, 2017a, 2017b). Considerando que um quarto dos cursos de 2010 tinham um prazo de integralização mínimo superior a quatro anos, entendeu-se necessário expandir temporalmente a análise. A restrição aos cursos com duração de quatro anos traria um importante viés por áreas do conhecimento. Cursos de engenharia e medicina, por exemplo, ficariam de fora da análise apresentada por possuírem prazo mínimo de integralização superior a quatro anos, não sendo, portanto, razoável estimar taxas de conclusão para esses cursos com base nos indicadores oficiais disponíveis até o momento. Por essa razão, esse trabalho replicou a metodologia da análise de trajetórias desenvolvida pela Deed/Inep ${ }^{10}$ até o ano de 2016 - totalizando, portanto, o acompanhamento por sete anos da coorte de ingressantes de 2010 - com duas modificações no tratamento das bases de dados (descritas no Apêndice C). A extensão do período de acompanhamento para sete anos possibilita o cálculo da taxa de conclusão para cursos com duração mínima de até seis anos, que correspondiam a 99,7\% dos cursos de 2010.

2.2.1 Taxas médias de conclusão, desistência e permanência dos cursos de graduação

Os resultados a seguir foram obtidos com base no acompanhamento longitudinal dos ingressantes nos cursos de graduação no ano de 2010. Procurando seguir a mesma metodologia do estudo publicado anteriormente (Brasil. Inep, 2017a), calculou-se, para cada curso de graduação, a quantidade de alunos ingressantes em 2010, que, ao final de um período de sete anos (2016), haviam concluído, desistido ou permaneciam matriculados em seu curso de origem. Dentre os três indicadores mencionados, a taxa média de conclusão (TMC) - indicador principal, tendo em vista as Estratégias $12.3 \mathrm{e}$ 13.8 do PNE - foi calculada de acordo com a seguinte fórmula:

$$
T M C_{2010 \_2016}=\frac{\text { alunos formados entre } 2010 \text { e } 2016 \text { que ingressaram em } 2010}{\text { ingressantes em } 2010 \text {-alunos falecidos entre } 2010 \text { e } 2016} \text { (4) }
$$

Complementares à TMC, foram também computadas a taxa média de desistência (TMD) - Fórmula 5 - e a taxa média de permanência (TMP) ao final do período de acompanhamento (Fórmula 6):

$$
T M D_{20102016}=\frac{\text { alunos desistentes entre } 2010 \text { e } 2016 \text { que ingressaram em } 2010}{\text { ingressantes em } 2010 \text {-alunos falecidos entre } 2010 \text { e } 2016}(5)
$$

\footnotetext{
${ }^{10}$ Os autores são gratos à equipe da Deed/Inep pelo auxílio técnico na replicação dos indicadores e assumem inteira responsabilidade pelos cálculos realizados.
} 


$$
\mathrm{TMP}_{2010 \_2016}=\frac{\text { ingressantes em } 2010 \text { matriculados no curso de origem em } 2016}{\text { ingressantes em } 2010 \text {-alunos falecidos entre } 2010 \text { e } 2016} \text { (6) }
$$

O Gráfico 8 apresenta as taxas médias de conclusão, desistência e permanência da coorte de ingressantes de 2010 no ano de 2016, por segmento e modalidade de ensino. Nota-se que a taxa média de conclusão dos cursos públicos presenciais, para a coorte de ingressantes de 2010, era de 45,8\% em 2016, cerca de metade do objetivo de 90\% estabelecido pela Estratégia 12.3 do PNE. Nesse grupo de cursos, 43,5\% dos ingressantes tiveram o vínculo com o curso interrompido (taxa de desistência) e 10,7\% continuavam matriculados no curso de origem (taxa de permanência), transcorridos sete anos após o ingresso. Nos cursos presenciais do segmento privado, por sua vez, a taxa média de conclusão, no período analisado, foi 4,7 pontos percentuais (p.p.) menor do que nos cursos públicos: 41,1\%. O segmento privado, portanto, também se encontra distante da meta de $75 \%$ para a taxa de conclusão média nos cursos presenciais, objetivo definido pela Estratégia 13.8 do PNE. Nos cursos privados presenciais, a taxa média de desistência foi 11,2 p.p. superior à média do segmento público para a mesma modalidade, embora a taxa de permanência tenha sido inferior à observada $(4,2 \%)$. Quanto aos cursos na modalidade a distância, nota-se menores taxas de conclusão e maiores taxas de desistência em relação aos cursos presenciais no mesmo período, mantido fixo o segmento avaliado.

É importante, contudo, analisar as taxas de conclusão, desistência e permanência conforme a área dos cursos, tendo em vista que a média pode não ser elucidativa de heterogeneidades (Andifes; Abruem; Brasil. MEC, 1996; Silva Filho et al., 2007; Cardoso, 2008; Rabelo; Cavenaghi, 2016). Por essa razão, apresenta-se, no Gráfico 9, as taxas médias de conclusão por grandes áreas do conhecimento. Uma vez que o foco do PNE é a elevação das taxas de conclusão dos cursos presenciais, são analisados, desse gráfico em diante, apenas os cursos dessa modalidade de ensino.

De modo semelhante ao identificado em trabalhos preliminares, citados no parágrafo anterior, constata-se, conforme Gráfico 9, que os cursos da área de saúde e bem-estar social possuem, em média, uma taxa de conclusão mais elevada, enquanto os cursos das áreas de ciências, matemática e computação apresentam, em média, uma taxa de conclusão mais baixa. Se comparados aos cursos do setor privado, os cursos do segmento público apresentam taxas médias de conclusão mais elevadas na maioria das áreas do conhecimento, enquanto o setor privado apresenta taxas médias de conclusão superiores ao setor público somente nas áreas de educação, serviços, humanidades e artes. 


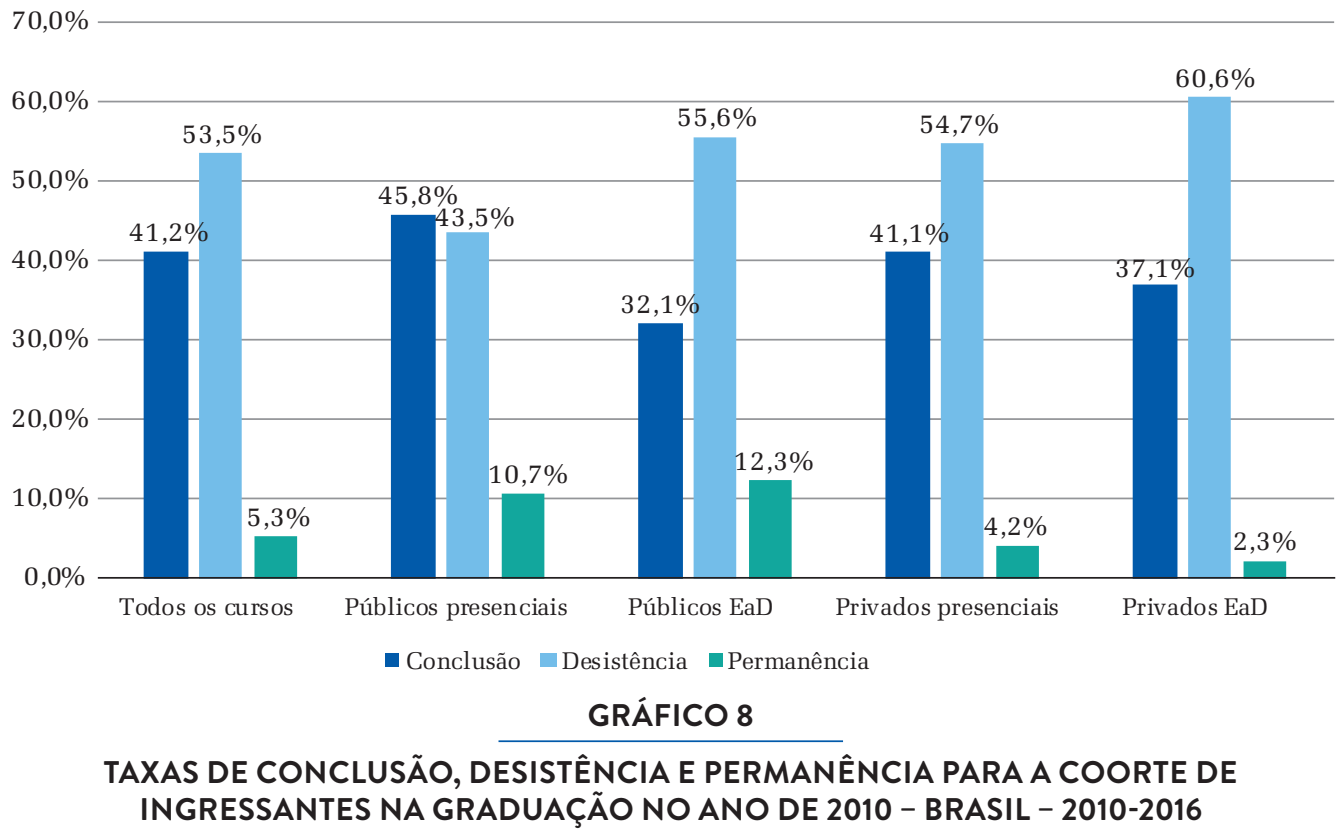

Fonte: Elaboração própria com base em dados do Censo da Educação Superior (2010-2016).

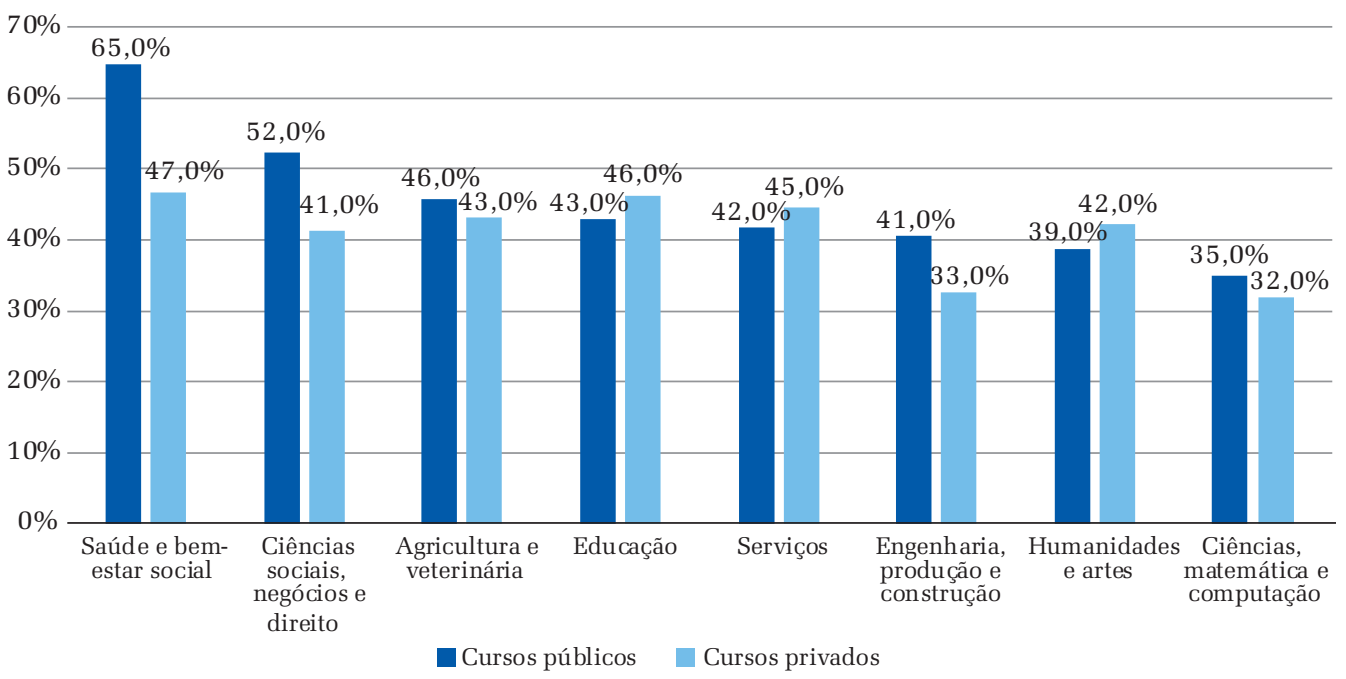

GRÁFICO 9

TAXAS MÉDIAS DE CONCLUSÃO DOS CURSOS, POR GRANDES ÁREAS DE CONHECIMENTO E SEGMENTO - BRASIL - 2010-2016 (EM \% DOS INGRESSANTES EM 2010 QUE CONCLUÍRAM O CURSO DE ORIGEM ATÉ O FINAL DE 2016)

Fonte: Elaboração própria com base em dados do Censo da Educação Superior (2010-2016).

É preciso considerar, todavia, que há uma diferente concentração dos cursos e áreas de conhecimento nos segmentos público e privado. Na grande área de educação, por exemplo, o segmento privado concentra mais de $70 \%$ dos alunos dos cursos 
presenciais de pedagogia e formação de professores em educação física. Por sua vez, o segmento público concentra a maior parte dos alunos nos cursos de formação de professores em matemática (66\%), química (76\%) e física (87\%), que apresentam maiores taxas de desistência. Desse modo, as taxas de conclusão e desistência do setor público e privado podem estar "contaminadas” pelas diferentes proporções de áreas e cursos em cada segmento.

Por essa razão, é necessário observar também a taxa média de conclusão em cada área de curso. Uma vez que no CES de 2010 havia 351 diferentes áreas de curso (variável “CO_OCDE”), é impraticável apresentar as taxas de conclusão para todas elas no escopo deste artigo. Desse modo, apresenta-se, no Gráfico 10, as taxas de conclusão de 28 áreas de cursos com mais de 4.000 ingressantes em 2010, tanto no segmento público quanto no segmento privado.

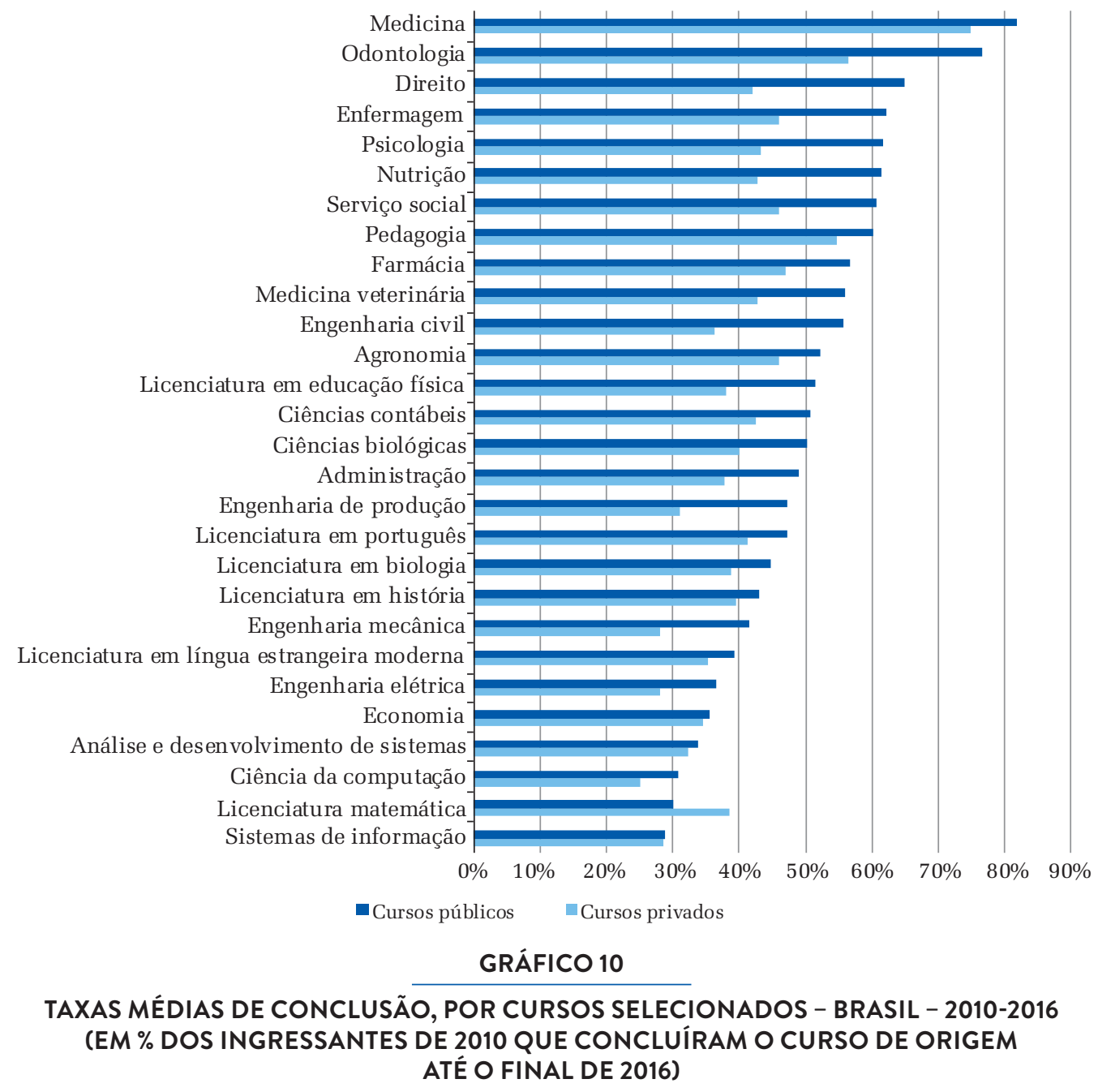

Fonte: Elaboração própria com base em dados do Censo da Educação Superior (2010-2016). 
No geral, entre as IES públicas, nenhuma área de curso foi capaz de atingir o objetivo de 90\% de taxa de conclusão. Ademais, os cursos públicos apresentam taxas médias de conclusão mais elevadas do que os cursos privados quando considerados os 28 cursos acima. A exceção são os cursos de formação de professores em matemática, área na qual o segmento privado formou 38,6\% dos ingressantes, de 2010 até 2016, enquanto o segmento público formou $30,1 \%$ dos ingressantes no mesmo período. Os cursos de medicina são aqueles que apresentam a maior taxa média de conclusão nos dois segmentos. No setor público, a taxa de conclusão média dos cursos de medicina foi de $81,7 \%$, e no setor privado de 74,8\%. Entre as IES privadas, apenas os cursos de medicina estão próximos de alcançar a taxa de conclusão de 75\% almejada pelo PNE. Sublinha-se, entretanto, que os cursos de medicina possuem duração mínima de seis anos e foi possível, até o momento, acompanhar a coorte de ingressantes por apenas sete anos.

Em relação aos cálculos da taxa de desistência e permanência em cursos públicos, 10,2\% dos ingressantes em medicina haviam desistido do curso ao final do período de acompanhamento (Gráfico 11), enquanto 8,1\% deles continuavam vinculados ao curso de origem (Gráfico 12). Ou seja, considerando hipoteticamente que não houvesse uma permanência dos estudantes ao final do acompanhamento, isto é, que todos se formassem, apenas os cursos de medicina teriam a possibilidade de chegar próximo do objetivo do PNE para a taxa de conclusão no segmento público. Portanto, há evidências de que o objetivo estabelecido no PNE foi superestimado para o conjunto dos cursos de graduação, pois, no segmento público, nem mesmo a área de cursos com melhor desempenho nesse quesito terá facilidade para alcançá-lo.

Entre os cursos com taxas de conclusão mais elevadas, acima de 60\%, há cinco cursos da grande área de saúde e bem-estar social (medicina, odontologia, enfermagem, nutrição e serviço social), dois cursos da área de ciências sociais, negócios e direito (direito e psicologia) e um curso da área de educação (pedagogia). Os demais cursos de formação de professores do segmento público apresentaram taxas médias de conclusão entre $40 \%$ e 50\%. A exceção é o curso de formação de professores em matemática, cuja taxa de conclusão de 30,1\% aproxima-se mais dos cursos da área de ciências, matemática e computação. Nessa área, a maior taxa de conclusão é do curso de ciências biológicas (50\%), que se aproxima mais das taxas médias dos cursos da área de educação.

As taxas de desistência por curso, apresentadas no Gráfico 11, espelham, em alguma medida, os resultados observados para as taxas de conclusão, porém com algumas notáveis diferenças. Alguns cursos de engenharia do segmento público, por exemplo, apresentaram taxas de permanência superiores (Gráfico 12) às taxas de desistência (Gráfico 11). Um em cada quatro alunos dos cursos públicos de engenharia elétrica e mecânica permaneceu com situação indefinida sete anos após o ingresso, não tendo concluído nem desistido do curso. 
Por sua vez, nos cursos de formação de professores em matemática, a taxa de conclusão do segmento público foi 9 p.p. abaixo do segmento privado, mas a taxa de desistência foi apenas 1 p.p. superior, o que revela um grande diferencial nas taxas de permanência. Por exemplo, nos cursos públicos de licenciatura em matemática, $11,0 \%$ dos alunos permaneciam matriculados sete anos após o ingresso, enquanto que no segmento privado esse percentual foi de apenas 3,5\%. Portanto, uma maior taxa de permanência do que de desistência também ocorre em graus variados nos mais diversos cursos.

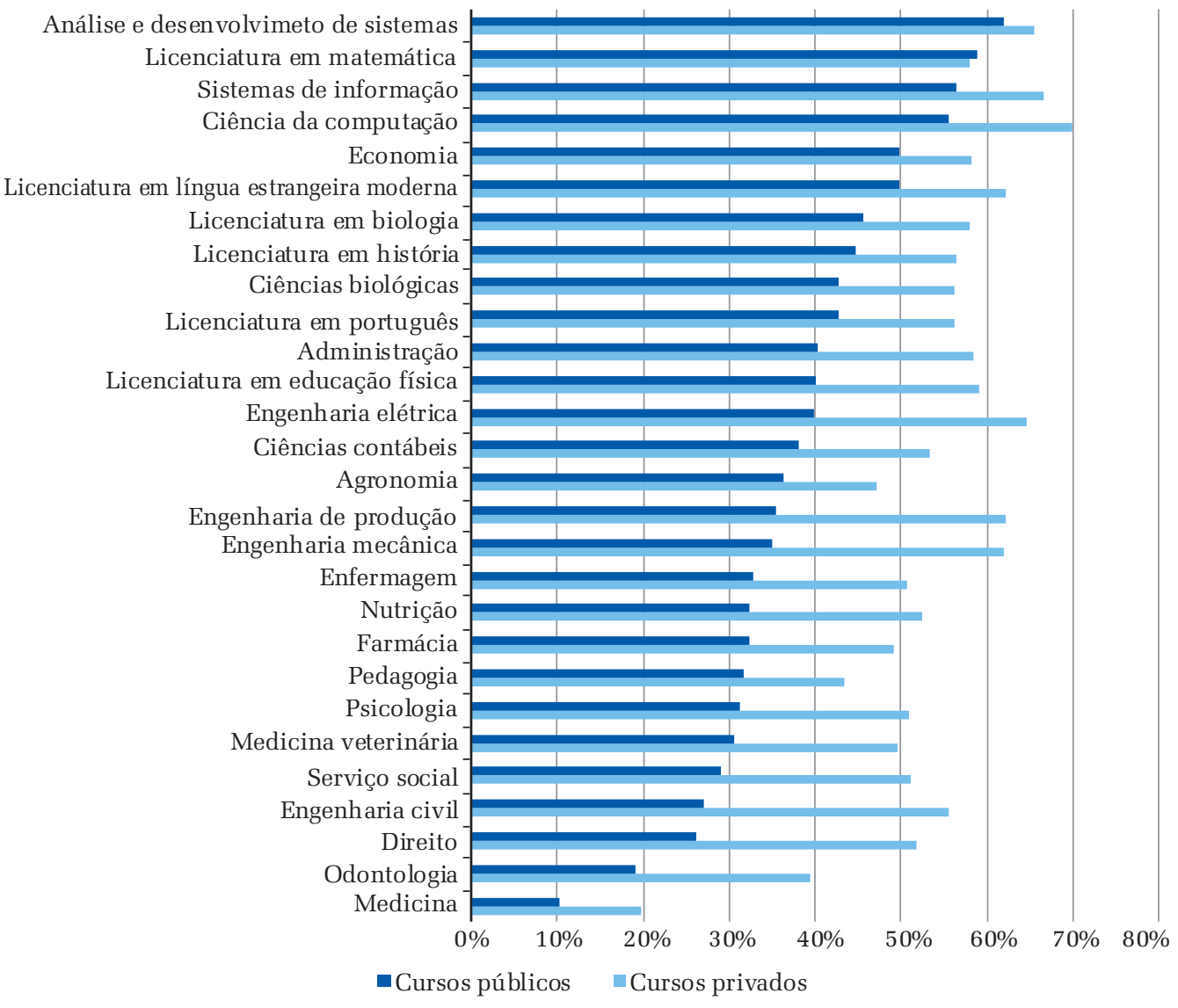

GRÁFICO 11

TAXAS MÉDIAS DE DESISTÊNCIA DAS ÁREAS DE CURSO SELECIONADAS - BRASIL - 20102016 (EM \% DOS INGRESSANTES DE 2010 QUE DESISTIRAM DO CURSO DE ORIGEM ATÉ O FINAL DE 2016)

Fonte: Elaboração própria com base em dados do Censo da Educação Superior (2010-2016).

Apesar de algumas especificidades, como as elencadas anteriormente, algumas evidências gerais podem ser traçadas em relação ao diferencial público-privado nas taxas de conclusão, permanência e desistência. Primeiro, os cursos públicos tendem a apresentar maiores taxas de conclusão do que os cursos no segmento privado. 
Porém, as taxas de desistência dos cursos privados superam às dos cursos públicos, e em maior grau do que a diferença observada entre os segmentos quanto às taxas de conclusão (Gráfico 11). Isso ocorre porque, nos cursos públicos, há um maior percentual de alunos que continuam matriculados nos cursos de origem, mesmo após o prazo mínimo de integralização (Gráfico 12). Deve-se ressaltar que isso não significa, necessariamente, que os alunos dos cursos públicos demoram mais para se formar, uma vez que as taxas de conclusão são quase sempre maiores nesse segmento, analisando-se o mesmo período. Significa, porém, que, no segmento privado, os alunos optam mais cedo pela quebra de vínculo com o curso, sendo que essa definição mais célere parece contribuir mais para a desistência do que para a conclusão. Uma hipótese é que a necessidade de definição mais rápida da situação de encerramento dos cursos no segmento privado encontra-se relacionada ao pagamento das mensalidades. É possível, por exemplo, que, diante da reprovação em algumas matérias, os alunos do segmento privado insistam menos em continuar matriculados. As taxas de permanência mais elevadas no segmento público também significam que, se o período de acompanhamento for estendido, é possível que as taxas de conclusão dos cursos públicos se elevem, enquanto há pouca margem para aumento das taxas de conclusão no segmento privado.

As não desprezíveis taxas de permanência após o período mínimo de integralização no setor público revelam um aspecto paradoxal da utilização do indicador de matrículas (como nas taxas brutas e líquidas de matrículas) para o monitoramento da expansão da educação superior. Entre dois cursos que apresentem o mesmo número de ingressos e a mesma taxa de conclusão, apresentará um maior número de matrículas aquele em que os alunos demorarem mais para se graduarem. $\mathrm{Na}$ verdade, uma elevada taxa de permanência pode contribuir mais para o crescimento das matrículas do que uma elevada taxa de conclusão. Por esse motivo, indicadores que levem em consideração o número de concluintes nos cursos de graduação devem também ser considerados para a indução de políticas mais eficientes de expansão da educação superior.

De forma semelhante à análise da taxa de ociosidade, cabe também perguntar se é possível encontrar uma concentração maior de cursos com taxas de conclusão elevadas em determinados tipos de IES. Uma análise de variância das taxas médias de conclusão por curso constatou que as diferenças entre as IES explicam um maior percentual da variabilidade da taxa média de conclusão dos cursos do que as diferenças entre as áreas, embora essas também expliquem um elevado percentual dessa variabilidade (Gráfico B4, Apêndice B). Ao contrário do que ocorreu com as taxas de ociosidade, as diferenças entre segmentos público e privado explicam pouco a variabilidade das taxas de conclusão se comparadas às diferenças entre as IES e se comparadas às áreas dos cursos. As diferenças entre os cursos individuais, entretanto, explicam quase metade dessa variabilidade, indicando que as causas da variação das taxas de conclusão demandam análises mais aprofundadas sobre as condições 
dos cursos individualmente e, talvez, até mesmo do perfil de seu alunado. Como foi possível induzir pelas análises anteriores, as diferenças entre os segmentos público e privado explicam mais a variação das taxas de desistência e de permanência do que a variação nas taxas de conclusão dos cursos (Gráficos B4 e B5, Apêndice B).

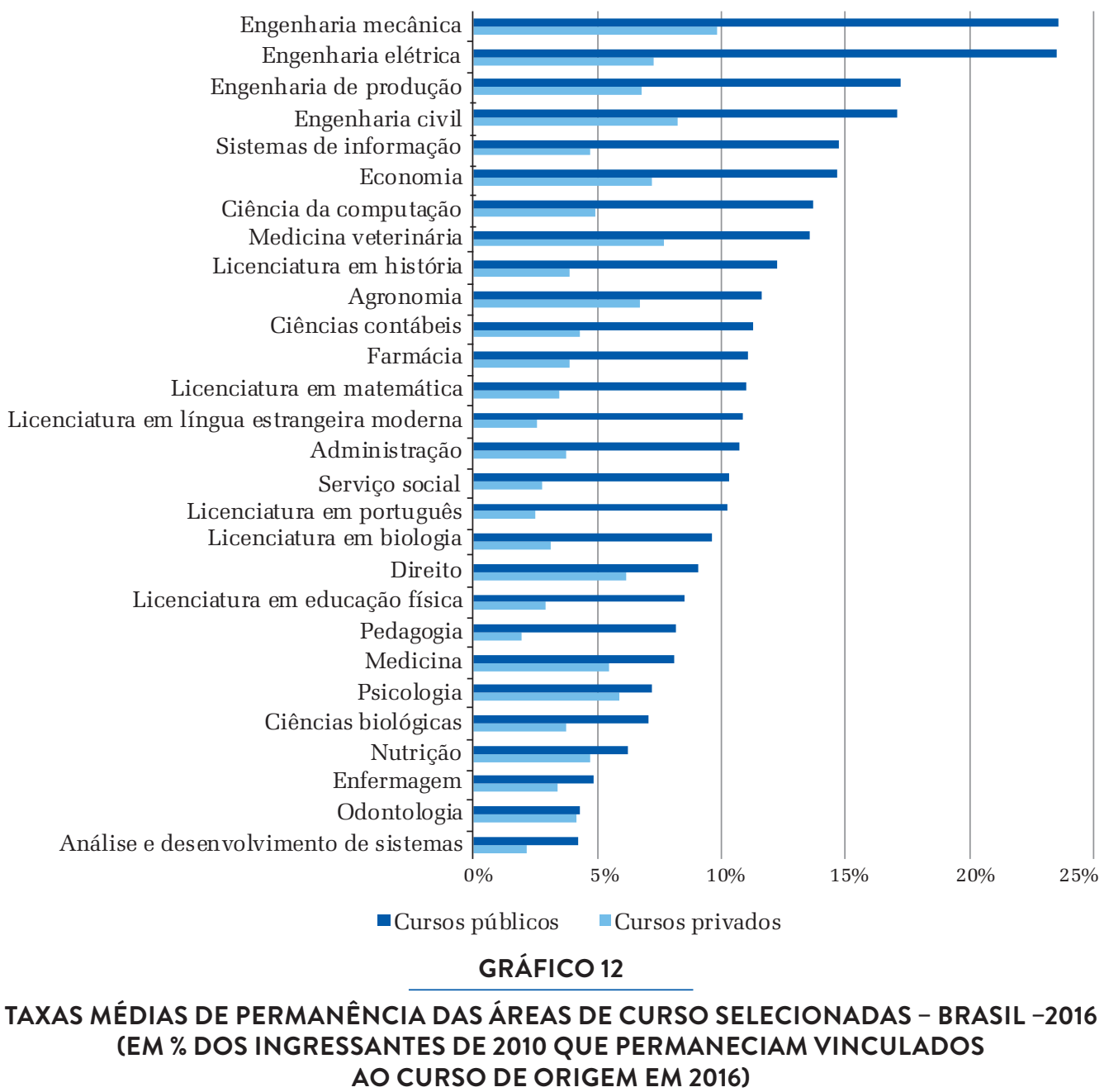

Fonte: Elaboração própria com base em dados do Censo da Educação Superior (2010-2016).

O universo da análise dos indicadores de fluxo aqui constituídos contempla 2.018 IES referentes à coorte de ingressantes em 2010 até o ano de 2016. Seria demasiadamente arbitrário e fugiria aos propósitos deste artigo identificar as taxas médias de conclusão de algumas delas de forma individualizada. ${ }^{11}$ Por essa razão,

\footnotetext{
${ }^{11}$ Gestores públicos, pesquisadores e administradores das IES interessados nessas informações individualizadas, por curso e por IES, podem consultar os indicadores oficiais, válidos para o período de 2010 a 2014, disponíveis no site: <http://portal.inep.gov.br/web/guest/indicadores-educacionais> .
} 
apresenta-se, no Gráfico 13, o percentual de cursos, por faixas de taxa de conclusão, para as IES de análise de acordo com sua categoria administrativa. Para a construção desse gráfico, foram mantidos apenas os cursos que tiveram mais de três ingressantes em 2010.

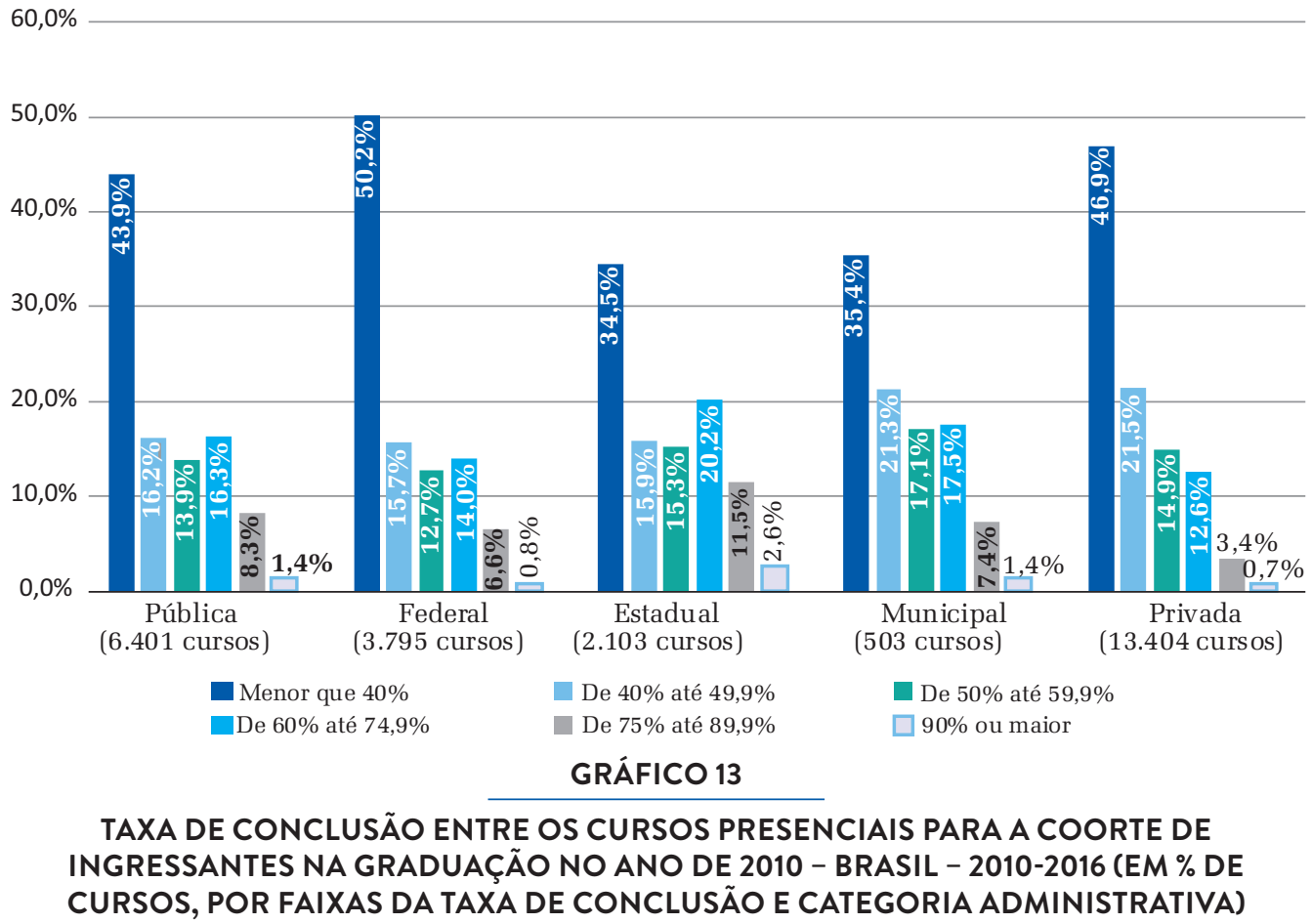

Fonte: Elaboração própria com base em dados do Censo da Educação Superior (2010-2016).

Observa-se que em todas as categorias administrativas há uma maior concentração de cursos com taxas de conclusão inferiores a 40\%. Na rede federal, metade dos cursos apresentou taxas de conclusão inferior a esse patamar. No segmento público, 39,9\% dos cursos apresentaram taxa de conclusão superior a 50\%, enquanto no segmento privado esse percentual foi de $31,4 \%$. No que tange aos objetivos do PNE, apenas 1,4\% dos cursos públicos apresentou taxa de conclusão superior a 90\%. O maior percentual de cursos que superaram esse patamar foi encontrado na rede estadual: $2,6 \%$. No segmento privado, $4,1 \%$ dos cursos tiveram taxa de conclusão superior a $75 \%$, apenas $0,7 \%$ superior a $90 \%$.

As pesquisas que procuraram investigar os fatores associados às elevadas taxas de desistência na graduação no Brasil e no exterior apontam para a contribuição de diversos fatores. Dentre eles, incluem-se as características dos alunos, como o engajamento com o curso, seu nível socioeconômico, os conhecimentos prévios adquiridos, o apoio da família e a necessidade de conciliar estudos e trabalho (Tinto, 1993; Baggi; Lopes, 2011). Outros dizem respeito às ações institucionais, como o 
engajamento do corpo docente e do corpo técnico administrativo no acolhimento dos estudantes (Tinto, 2012), a adequação dos currículos à realidade do alunado e a existência de políticas de permanência estudantil (Andifes; Abrumes; Brasil. MEC, 1996). Por fim, um terceiro conjunto de fatores está relacionado ao nível de seletividade e ao prestígio dos cursos e das IES (Tinto, 1993; Silva Filho et al., 2007).

Entre esses fatores, aqueles que dizem respeito às ações institucionais, sejam elas empreendidas pelas próprias IES, ou implementadas por políticas públicas mais amplas - federais, estaduais ou municipais - são, possivelmente, os que trazem maior potencial de redução das elevadas taxas de desistência nos cursos de graduação no médio prazo (Tinto, 2012). Nesse sentido, pode ser de grande valia um estudo mais detalhado sobre as experiências dos cursos e IES que possuem baixas taxas de desistência e elevadas taxas de conclusão dos alunos. Estudos que identifiquem os fluxos de mobilidade entre cursos podem ser úteis também para o desenvolvimento de novas ações institucionais, tanto no sentido de expansão dos cursos mais cobiçados quanto de políticas que visem um maior esclarecimento dos candidatos à graduação sobre as características dos cursos almejados e de seu respectivo mercado de trabalho.

\subsection{AMPLIAR AS VAGAS EM CURSOS NOTURNOS}

A terceira proposta do PNE para a otimização da capacidade instalada nas instituições públicas é a oferta de pelo menos um terço das vagas dos cursos presenciais de graduação no período noturno (Estratégia 12.3). A oferta de vagas em cursos noturnos costuma ser associada a uma maior democratização do acesso à graduação, especialmente para os alunos mais desfavorecidos economicamente, para os quais o trabalho diurno concomitante aos estudos é muitas vezes um imperativo (Pacheco; Ristoff, 2004). Para muitos desses alunos, a condição inicial é a de trabalhador, e a procura pela educação superior é um modo de melhorar sua inserção no mercado de trabalho (Bittar; Almeida; Veloso, 2008).

A associação entre ampliação da oferta de vagas no período noturno e uma maior democratização do acesso à educação superior encontra ressonância na Constituição Federal, na Lei de Diretrizes e Bases da Educação Nacional e no primeiro Plano Nacional de Educação. Esse arcabouço legal estabelece a obrigatoriedade do Estado de ofertar "[...] ensino noturno regular, adequado às condições do educando" (Brasil, 1988, art. 208), de garantir aos estudantes trabalhadores "[...] condições de acesso e permanência na escola” (Brasil, 1996, art. 4º), e que os cursos noturnos de graduação "assegurem ao aluno-trabalhador o ensino de qualidade a que têm direito nas mesmas condições de que dispõem os estudantes do período diurno” (Brasil, 2001, p. 9).

O diagnóstico de que existem, nas IES públicas, mais vagas e matrículas nos períodos diurnos do que no período noturno, pode ser visto como um desperdício de recursos e como uma barreira à maior inclusão social, como apontam Pacheco e Ristoff (2004, p. 12): 
Com laboratórios, bibliotecas, salas de aula e instalações já existentes, fica evidente que se tornaria sensivelmente menos dispendioso promover a expansão de vagas nas IES públicas existentes mediante a utilização do horário noturno ainda amplamente ocioso. Se as IES públicas abrigam, hoje, 674.916 alunos nos seus cursos diurnos, não há por que imaginar que tal número não possa ser semelhante ao dos cursos noturnos. A simples equivalência de utilização do espaço e das instalações existentes nos dois turnos poderia significar, em quatro anos, um aumento nada desprezível de 298.177 matrículas, ou algo em torno de 75 mil vagas/ano.

$\mathrm{Na}$ ocasião em que os autores citados desenvolveram tal argumentação, os dados mais recentes disponíveis indicavam que as vagas ofertadas no período noturno nas instituições federais de educação superior (Ifes) correspondiam a apenas 24,8\% do total. Entretanto, se considerarmos o objetivo da Estratégia 12.3 de oferecimento de um terço das vagas públicas no turno noturno, verifica-se que esse objetivo já havia sido atingido à época da promulgação do PNE (Gráfico 14). No ano de 2016, o turno noturno respondeu por $41,8 \%$ da oferta de vagas presenciais das IES públicas. Essa proporção de cursos noturnos não apresentou grandes variações nos últimos anos. Nota-se também que o período noturno oferece mais vagas no segmento público (14,4\% e 7,6\% do total de vagas, respectivamente) do que os períodos matutino e vespertino somados. Os períodos diurnos somente ofertam mais vagas do que o período noturno por causa da ampla oferta de cursos integrais, que respondem por $36,2 \%$ das vagas nas IES públicas. É possível que a adaptação dos currículos dos cursos integrais para o período noturno não seja fácil, sendo necessária para isso uma análise de cada área de curso, o que foge ao escopo deste artigo.

Desse modo, a elevada prevalência de cursos integrais pode ser uma das causas pelas quais o percentual de vagas noturnas ofertadas na rede federal é inferior à média do setor público (Gráfico 15). Apesar disso, a oferta de vagas noturnas na rede federal é a maior em termos absolutos - entre as três redes públicas - e também alcança o objetivo fixado pela Estratégia 12.3 do PNE. Nessa rede, as vagas noturnas alcançam o patamar de $35,0 \%$ das vagas totais e também superam, como nas demais redes, as vagas matutinas e vespertinas somadas. 


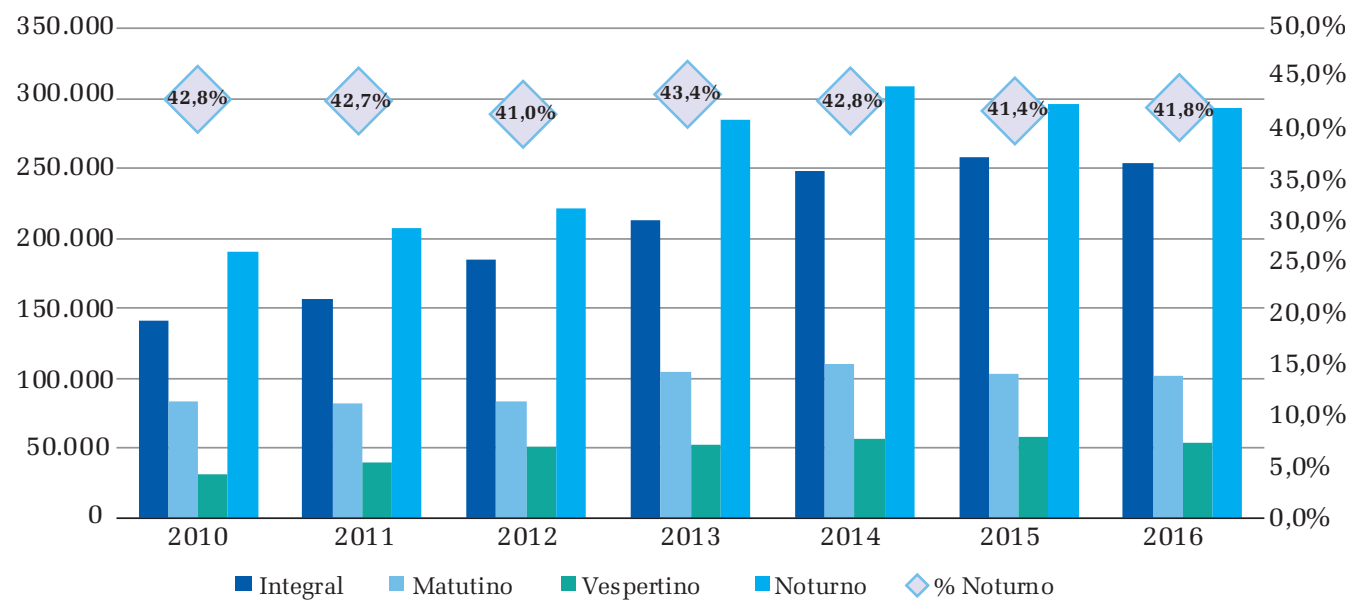

GRÁFICO 14

\section{OFERTA DE VAGAS, POR TURNO E PERCENTUAL DE VAGAS NOTURNAS NOS CURSOS PÚBLICOS PRESENCIAIS - BRASIL - 2010-2016}

Fonte: Elaboração própria com base em dados do Censo da Educação Superior (2010-2016).

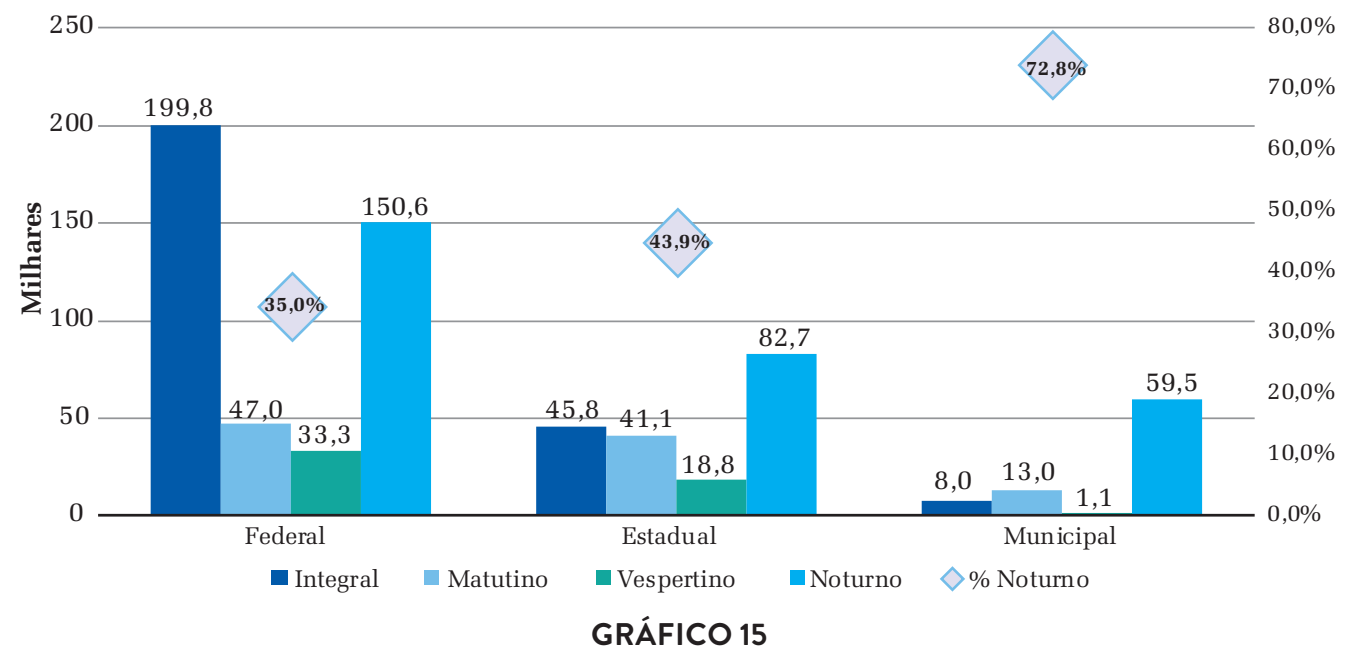

OFERTA DE VAGAS, POR CATEGORIA ADMINISTRATIVA E TURNO NOS CURSOS PÚBLICOS PRESENCIAIS (VAGAS POR TURNO, EM MILHARES, E PERCENTUAL DE VAGAS NOTURNAS EM RELAÇÃO AO TOTAL) - BRASIL - 2016

Fonte: Elaboração própria com base em dados do Censo da Educação Superior (2016).

Assim como nas seções anteriores, é importante verificar a heterogeneidade da oferta em turnos diurnos, vespertinos e noturnos, por curso. A oferta de vagas nos três períodos constitui uma possibilidade de expansão das vagas, mantida a infraestrutura existente. Sublinha-se, todavia, como fizeram Pacheco e Ristoff (2004), que a expansão dos cursos para o turno noturno requer mais do que instalações e espaço disponível, 
sendo necessária a contratação de professores e funcionários que possam atender os alunos nesse horário. Assim, definimos o potencial de expansão de vagas noturnas em cursos que oferecem mais vagas no período matutino ou vespertino, conforme Equação 7.

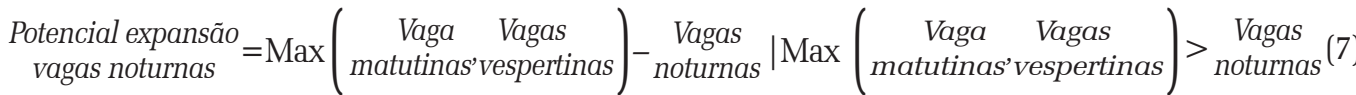

Essa fórmula significa que quando um curso oferece mais vagas no turno matutino ou vespertino do que no turno noturno, considera-se essa diferença como um potencial de expansão do turno noturno. Os resultados desse cálculo, para o ano de 2016, são apresentados na Tabela 3. Nota-se que 1.438 cursos públicos ofertaram mais vagas no período matutino ou vespertino do que no período noturno em todo o Brasil. Caso as vagas noturnas nesses cursos fossem iguais às vagas ofertada no período matutino ou vespertino, seria gerada uma expansão de 65.179 vagas públicas, aproveitando-se a infraestrutura física existente nos cursos. A área de educação é a que apresenta maior potencial nesse sentido, podendo gerar mais de 24 mil vagas noturnas em seus 575 cursos. Grande parte do potencial de expansão concentra-se na região Nordeste, justamente o local de menor escolaridade média da população jovem (Santos, 2016), onde 23.377 vagas noturnas poderiam ser criadas.

TABELA 3

POTENCIAL DE EXPANSÃO DO TURNO NOTURNO EM CURSOS QUE OFERECEM MAIS VAGAS NO TURNO MATUTINO OU VESPERTINO - BRASIL - 2016 (EM NÚMERO DE VAGAS, POR GRANDE ÁREA DE CONHECIMENTO E REGIÃO)

\begin{tabular}{|c|c|c|c|c|c|c|c|}
\hline \multirow{2}{*}{ Áreas do conhecimento } & \multicolumn{2}{|c|}{ Brasil } & Norte & Nordeste & Sudeste & Sul & Centro- \\
\hline & Cursos & \multicolumn{6}{|c|}{ Potencial de expansão de vagas noturnas } \\
\hline Todas as áreas & 1.438 & 65.179 & 11.973 & 23.377 & 16.752 & 7.783 & 5.294 \\
\hline Educação & 575 & 24.226 & 6.981 & 9.967 & 2.787 & 1.986 & 2.505 \\
\hline $\begin{array}{l}\text { Engenharia, produção e } \\
\text { construção }\end{array}$ & 181 & 9.669 & 2.180 & 2.519 & 3.522 & 973 & 475 \\
\hline $\begin{array}{l}\text { Ciências sociais, negócios } \\
\text { e direito }\end{array}$ & 182 & 9.044 & 837 & 2.959 & 3.351 & 1.057 & 840 \\
\hline $\begin{array}{l}\text { Ciências, matemática e } \\
\text { computação }\end{array}$ & 160 & 7.537 & 935 & 2.782 & 2.670 & 720 & 430 \\
\hline Saúde e bem-estar social & 69 & 3.385 & 200 & 1.311 & 1.153 & 542 & 179 \\
\hline Agricultura e veterinária & 69 & 3.253 & 476 & 1.572 & 720 & 365 & 120 \\
\hline Serviços & 62 & 3.239 & 125 & 1.346 & 1.040 & 568 & 160 \\
\hline Humanidades e artes & 98 & 3.016 & 229 & 921 & 524 & 1.043 & 299 \\
\hline Área básica de ingresso & 42 & 1.810 & 10 & 0 & 985 & 529 & 286 \\
\hline
\end{tabular}

Fonte: Elaboração própria com base em dados do Censo da Educação Superior (2016). 


\section{CONSIDERAÇÕES SOBRE O POTENCIAL DA OTIMIZAÇÃO DA CAPACIDADE INSTALADA SOBRE OS NIVVEIS ATUAIS DE MATRÍCULAS}

Nessa seção são sistematizados os resultados dos exercícios que buscam estimar o quanto falta para alcançar os objetivos da Meta 12 do PNE em termos de alunos e matrículas nos cursos de graduação, e estimar, por meio da construção de cenários hipotéticos e ilustrativos, quanto a redução da ociosidade de vagas iniciais, a diminuição das taxas de desistência de matrículas e a ampliação de vagas nos cursos noturnos podem contribuir para o alcance desses objetivos.

A Tabela 4 reporta os quantitativos necessários para o cumprimento da meta de expansão da educação superior do PNE. Ao observar essa tabela, torna-se claro que o objetivo da Meta 12 mais distante de ser cumprido é o de expansão das matrículas no segmento público. Enquanto é necessário que se aumente um pouco mais de $40 \%$ o total de alunos na graduação e a quantidade de jovens de 18 a 24 anos com acesso a esse nível de ensino, esse percentual de aumento deveria ser de quase 90\% no segmento público. No que diz respeito às matrículas privadas, seria suficiente um aumento na ordem de 30\%, também em relação a 2016. Nas subseções a seguir, são realizados exercícios de simulação para verificar como a melhoria dos indicadores de eficiência apresentados na seção anterior pode auxiliar no cumprimento dessas metas.

TABELA 4

QUANTO FALTA PARA CUMPRIR A META 12 DO PNE - BRASIL

\begin{tabular}{l|l|l|l|l|} 
& $\begin{array}{c}\text { Situação } \\
\mathbf{( 2 0 1 6 )}\end{array}$ & $\begin{array}{c}\text { Meta } \\
\mathbf{( 2 0 2 4 )}\end{array}$ & $\begin{array}{c}\text { Quanto falta } \\
\mathbf{( 2 0 1 6 - 2 0 2 4 )}\end{array}$ & $\begin{array}{c}\text { Crescimento } \\
\text { necessário } \\
\mathbf{( 2 0 1 6 - 2 0 2 4}\end{array}$ \\
\hline $\begin{array}{l}\text { Total de alunos } \\
\text { na graduação } \\
\text { (Pnad Contínua) }\end{array}$ & 8.052 .908 & 11.414 .356 & 3.361 .448 & $41,7 \%$ \\
\hline $\begin{array}{l}\text { Jovens de 18 a 24 } \\
\text { Com acesso à graduação } \\
\text { (Pnad Contínua) }\end{array}$ & 5.327 .726 & 7.533 .475 & 2.205 .749 & $41,4 \%$ \\
\hline $\begin{array}{l}\text { Matrículas ativas na graduação } \\
\text { (CES) }\end{array}$ & 8.048 .701 & 11.644 .922 & 3.596 .221 & $44,7 \%$ \\
\hline Matrículas públicas (CES) & 1.990 .078 & 3.740 .270 & 1.750 .192 & $87,9 \%$ \\
\hline Matrículas privadas (CES) & 6.058 .623 & 7.904 .652 & 1.846 .029 & $30,5 \%$ \\
\hline
\end{tabular}

Fonte: Elaboração própria com base em dados do Censo da Educação Superior (2016) e da Pnad Contínua (2017) - 2º trimestre/IBGE. 


\subsection{CENÁRIOS DE IMPACTO DA REDUÇÃO DA TAXA DE OCIOSIDADE SOBRE A NECESSIDADE DE NOVAS VAGAS}

Verificou-se, na seção 2.1, que os segmentos público e privado apresentaram, no ano de 2016, taxas médias de ociosidade de vagas iniciais de 15,0\% e 69,5\%, respectivamente. Serão trabalhados dois cenários para se estimar o impacto da redução da ociosidade das vagas sobre o total de matrículas. No primeiro cenário, as vagas ociosas em ambos os segmentos são reduzidas à metade. No segundo cenário, dois terços das vagas ociosas são preenchidas. Para conversão de vagas ocupadas por novos ingressantes em matrículas, será considerada a mesma proporção de matrículas por ingressante observada em ambos os segmentos no ano de 2016, assumindo que o aumento no número de matrículas será proporcional ao crescimento no número de ingressantes. Esses dois cenários são representados no Gráfico 16.

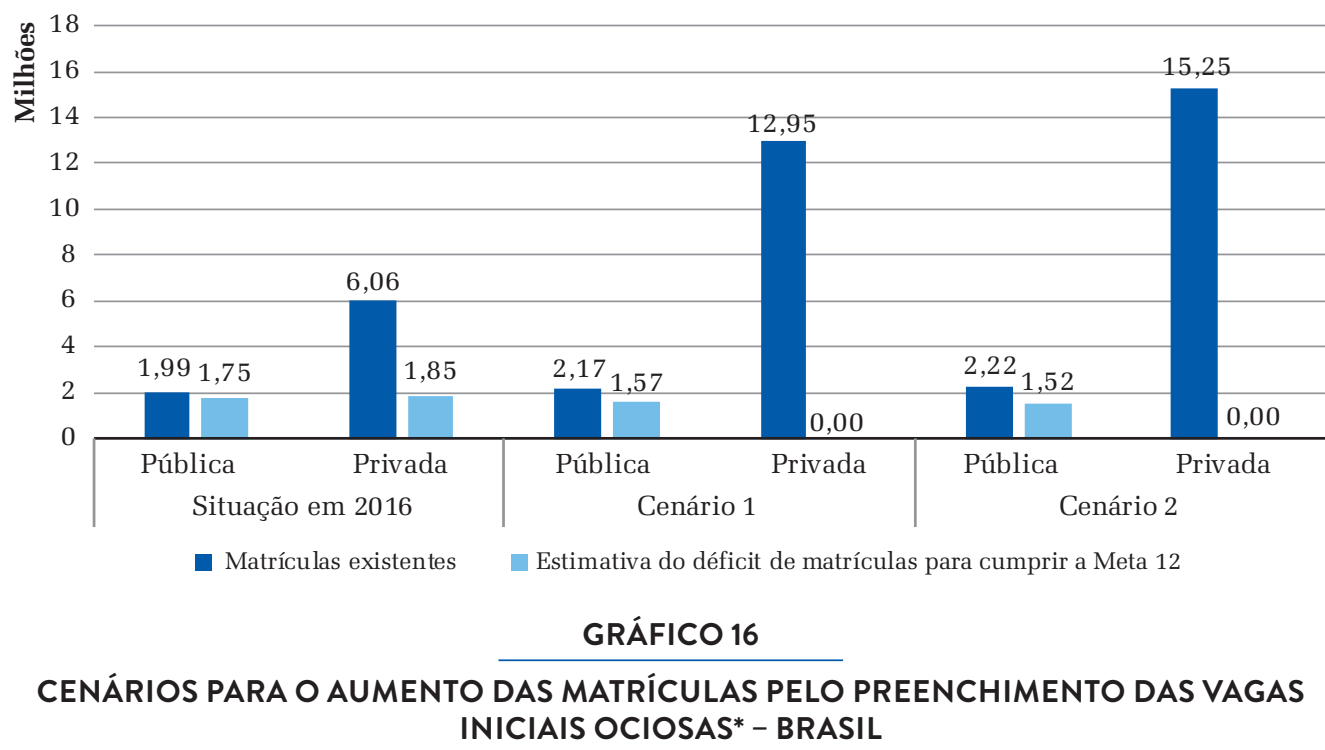

Fonte: Elaboração própria com base em dados do Censo da Educação Superior (2016) e da Pnad Contínua (2017) - $2^{\circ}$ trimestre/IBGE.

* No primeiro cenário são preenchidas metade das vagas ociosas. No segundo cenário, são preenchidos dois terços das vagas ociosas.

No primeiro cenário, a redução na taxa de ociosidade permite que a expansão necessária do segmento público para cumprir a meta do PNE seja reduzida em 10\%, de 1,75 milhão para 1,57 milhão. No segundo cenário, a quantidade de matrículas públicas necessárias cai para 1,52 milhão, ou uma redução de 13,4\% em relação ao patamar de 2016. No segmento privado, já no primeiro cenário, a redução na taxa de ociosidade permitiria anular o déficit de vagas em relação aos objetivos do PNE. Na verdade, bastaria uma redução de $37,6 \%$ das vagas iniciais ociosas no segmento privado para o cumprimento da meta do setor. 


\subsection{CENÁRIOS DE IMPACTO DA REDUÇÃO DA TAXA DE DESISTENNCIA SOBRE A NECESSIDADE DE NOVAS VAGAS}

Na análise das taxas de conclusão, verificou-se que 45,8\% dos ingressantes no ano de 2010 dos cursos públicos presenciais haviam concluído seu curso de origem até o final de 2016. Nos cursos presenciais privados, essa taxa foi de 41,1\%. Em ambos os casos, esses indicadores encontram-se muito distantes do objetivo fixado pelas Estratégias 12.3 e 13.8 do PNE. As baixas taxas de conclusão nos cursos públicos e privados, todavia, podem ser explicadas por elevadas taxas de desistência, ou por elevadas taxas de permanência no curso após o prazo mínimo para sua conclusão.

A construção de projeções futuras para as taxas de matrículas com base em vários cenários de redução da taxa de desistência e/ou de permanência não será objeto deste artigo, embora mereça um estudo a parte. Tal construção envolveria pressupostos sobre o número de ingressantes nos próximos anos, até o final do PNE, e sobre o comportamento anual das taxas de conclusão, desistência e permanência de cada coorte de ingressantes, de 2017 a 2024. Essa tarefa não é trivial, uma vez que essas taxas variam em função da área do curso, do prestígio das IES, do tempo mínimo de integralização de cada curso, e, provavelmente também em função de características sociais e econômicas do país. Entretanto, realiza-se aqui um exercício retrospectivo: em quanto as matrículas do ano de 2016 seriam acrescentadas se as taxas de desistência fossem reduzidas pela metade? Para realizar esse exercício foi necessário calcular as taxas médias de desistência para todas as coortes de ingressantes entre 2010 e 2016, replicando a mesma metodologia utilizada para a coorte de 2010. As taxas médias de desistência acumuladas, por ano, para cada coorte de ingressos entre 2010 e 2016 são apresentadas na Tabela 5.

TABELA 5

TAXA MÉDIA DE DESISTÊNCIA ACUMULADA DOS CURSOS DE GRADUAÇÃO, POR COORTE DE INGRESSOS E SEGMENTO - BRASIL - 2010-2016

Taxa média de desistência acumulada

\begin{tabular}{|c|c|c|c|c|c|c|c|c|c|}
\hline \multirow{2}{*}{$\begin{array}{l}\text { Coorte } \\
\text { de } \\
\text { ingressos }\end{array}$} & \multirow{2}{*}{ Segmento } & \multirow{2}{*}{ Ingressos } & \multicolumn{7}{|c|}{ Taxa média de desistência acumulada } \\
\hline & & & $1^{0}$ ano & $2^{0}$ ano & $3^{0}$ ano & $4^{0}$ ano & $5^{0}$ ano & $6^{0}$ ano & $7^{0}$ ano \\
\hline \multirow{2}{*}{2010} & Pública & 478.961 & $6,5 \%$ & $17,2 \%$ & $26,7 \%$ & $33,1 \%$ & $38,2 \%$ & $41,6 \%$ & $44,4 \%$ \\
\hline & Privada & 1.799 .539 & $11,4 \%$ & $28,1 \%$ & $37,5 \%$ & $43,7 \%$ & $48,5 \%$ & $52,0 \%$ & $55,9 \%$ \\
\hline \multirow{2}{*}{2011} & Pública & 492.646 & $6,9 \%$ & $19,7 \%$ & $29,1 \%$ & $36,1 \%$ & $40,6 \%$ & $44,5 \%$ & \\
\hline & Privada & 1.889 .228 & $12,5 \%$ & $27,3 \%$ & $36,8 \%$ & $44,0 \%$ & $49,2 \%$ & $54,1 \%$ & \\
\hline \multirow{2}{*}{2012} & Pública & 520.837 & $8,4 \%$ & $21,5 \%$ & $30,4 \%$ & $36,9 \%$ & $42,0 \%$ & & \\
\hline & Privada & 2.218 .565 & $13,6 \%$ & $28,7 \%$ & $38,4 \%$ & $45,9 \%$ & $52,6 \%$ & & \\
\hline \multirow{2}{*}{2013} & Pública & 511.012 & $8,3 \%$ & $20,7 \%$ & $30,1 \%$ & $37,3 \%$ & & & \\
\hline & Privada & 2.316 .872 & $11,6 \%$ & $26,6 \%$ & $37,3 \%$ & $46,7 \%$ & & & \\
\hline
\end{tabular}


TABELA 5

TAXA MÉDIA DE DESISTÊNCIA ACUMULADA DOS CURSOS DE GRADUAÇÃO, POR COORTE DE INGRESSOS E SEGMENTO - BRASIL - 2010-2016

\begin{tabular}{|c|c|c|c|c|c|c|c|c|c|}
\hline \multirow{2}{*}{$\begin{array}{c}\text { Coorte } \\
\text { de } \\
\text { ingressos }\end{array}$} & \multirow{2}{*}{ Segmento } & \multirow[b]{2}{*}{ Ingressos } & \multicolumn{7}{|c|}{ Taxa média de desistência acumulada } \\
\hline & & & $1^{0}$ ano & $2^{0}$ ano & $3^{0}$ ano & $4^{0}$ ano & $5^{0}$ ano & $6^{0}$ ano & $7^{0}$ ano \\
\hline \multirow{2}{*}{2014} & Pública & 534.572 & $8,5 \%$ & $21,5 \%$ & $31,0 \%$ & & & & \\
\hline & Privada & 2.555 .737 & $13,9 \%$ & $29,9 \%$ & $41,9 \%$ & & & & \\
\hline \multirow{2}{*}{2015} & Pública & 532.995 & $9,1 \%$ & $21,9 \%$ & & & & & \\
\hline & Privada & 2.431 .811 & $13,9 \%$ & $31,4 \%$ & & & & & \\
\hline \multirow{2}{*}{2016} & Pública & 535.633 & $10,4 \%$ & & & & & & \\
\hline & Privada & 2.456 .152 & $19,1 \%$ & & & & & & \\
\hline
\end{tabular}

Fonte: Elaboração própria com base em dados do Censo da Educação Superior (2010-2016).

Nessa simulação, nota-se uma tendência de aumento das taxas médias de desistência, tanto no segmento público quanto no segmento privado no período analisado. Parte desse aumento decorre do fato de que para as coortes de ingressantes mais recentes há um menor período de acompanhamento, diminuindo, desse modo, a possibilidade de captar, nos anos seguintes, o reingresso no curso de origem para aqueles desistentes temporários. Não obstante, mesmo se forem desconsiderados os reingressos nos anos seguintes, utilizando apenas a taxa de desistência em cada ano do CES de forma individual, não há grandes alterações na tendência de aumento da taxa de desistência no primeiro ano.

Entre os alunos desistentes da coorte ingressante em 2010, é razoável assumir que poderiam encontrar-se na condição de matriculado ou de concluinte em 2016 apenas aqueles cujo o curso tem um prazo mínimo de integralização de sete anos ou mais. Em cursos de menor duração, seria provável que parte dos ingressantes de 2010 já tivessem concluído o curso de origem antes de 2016, caso não tivessem desistido da matrícula. Raciocínio semelhante se aplica para os desistentes que ingressaram na coorte de 2011. Caso eles não tivessem desistido do curso, poderiam encontra-se na condição de matriculado ou concluinte em 2016 aqueles cujo curso tem uma duração mínima de seis anos ou mais - essa lógica foi aplicada sucessivamente para as coortes de 2012 a 2016. O número de alunos desistentes das coortes de ingressantes de 2010 a 2016 que poderiam encontrar-se na condição de matriculados ou concluintes no ano de 2016, caso não tivessem desistido do curso, é apresentado na Tabela 6. 


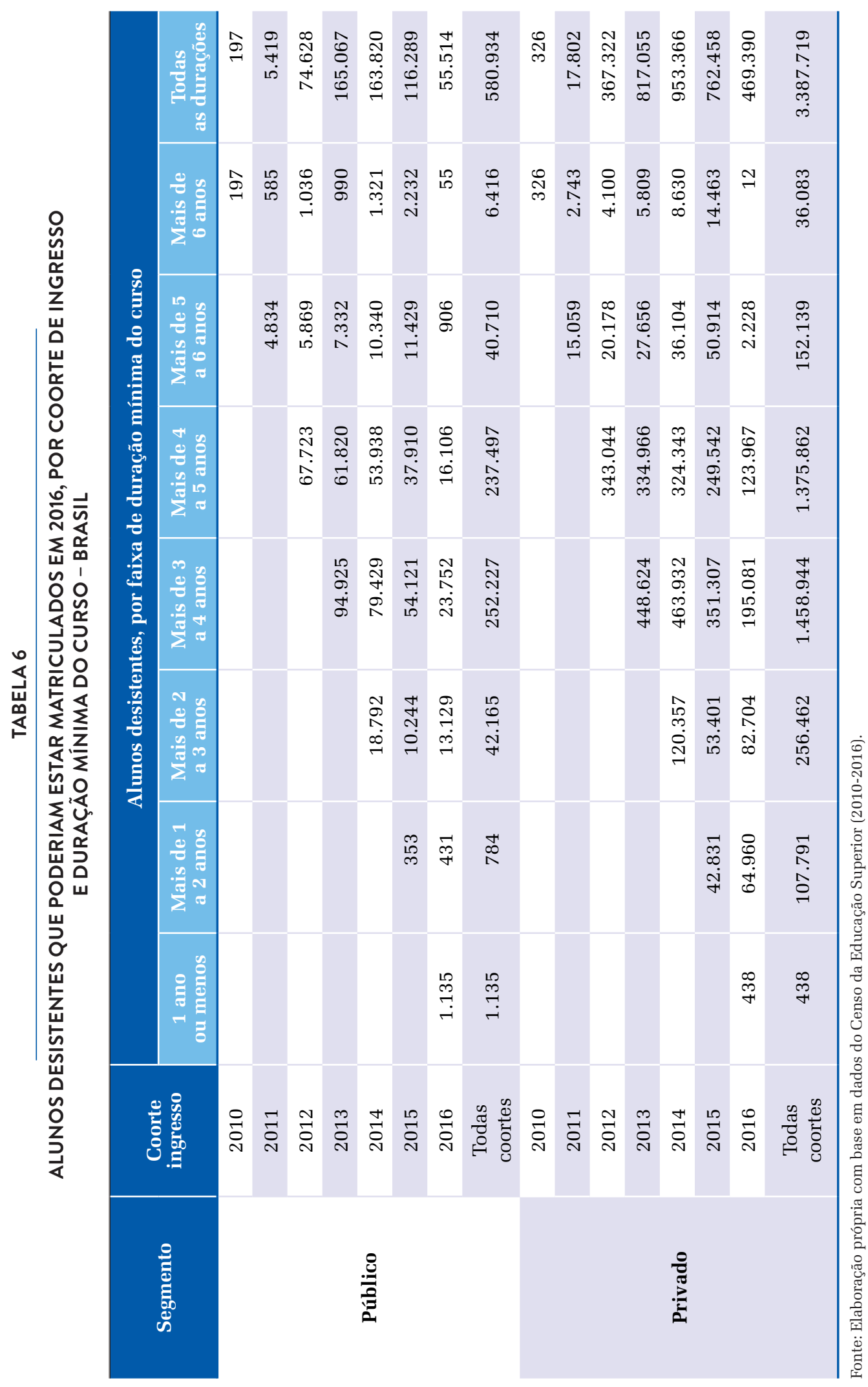


Conforme a tabela anterior, não é surpresa o grande número de alunos desistentes nos cursos com duração de três a cinco anos, uma vez que esses cursos concentram a maior parte das matrículas. Todavia, o exercício nos permite dizer que poderiam existir, se não houvesse desistência de curso entre 2010 e 2016, no mínimo, 580 mil matrículas adicionais no segmento público e 3,38 milhões no segmento privado. Cabe mencionar que essa é uma estimativa conservadora, pois considera-se que os alunos desistentes iriam continuar vinculados ao curso apenas até o prazo mínimo de integralização, quando, na verdade, muitos alunos continuam matriculados após esse prazo. Todavia, há que se mencionar que esse também é um cenário irrealizável, pois sempre há algum nível de desistência do curso, pelos motivos mais diversos.

Tendo em vista as limitações colocadas acima, simulou-se mais dois cenários. No primeiro, a taxa de desistência é reduzida pela metade, no segundo em dois terços. O impacto dessa redução sobre o quantitativo de matrículas de 2016 é apresentado no Gráfico 17.

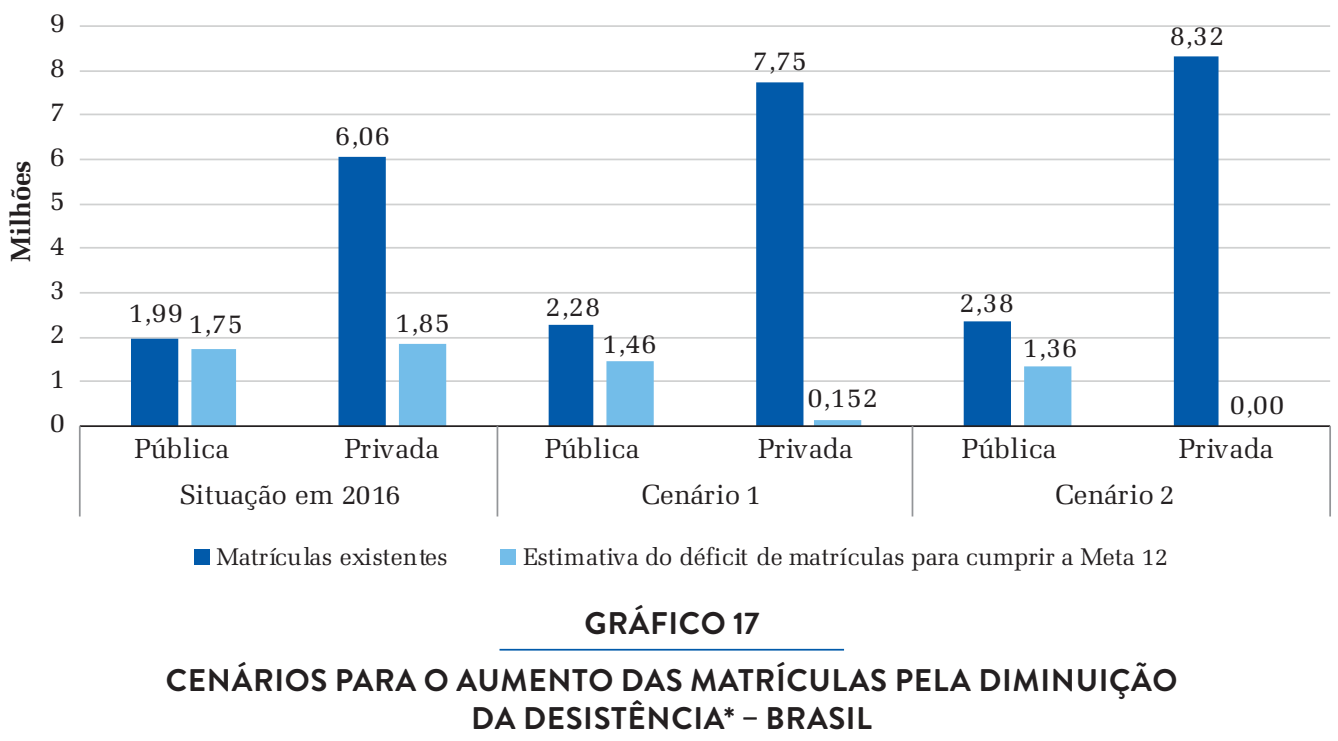

Fonte: Elaboração própria com base em dados do Censo da Educação Superior (2010-2016) e da Pnad Contínua (2017) $2^{\circ}$ trimestre/IBGE.

* No primeiro cenário a desistência entre 2010 e 2016 é reduzida à metade. No segundo cenário, a um terço.

Com base no exercício proposto, conclui-se que, se a taxa média de desistência de cursos caísse uniformemente pela metade, entre 2010 e 2016, a necessidade de expansão do segmento público cairia de 1,75 milhão de matrículas para 1,46 milhão. Se a taxa média de desistência fosse reduzida a um terço, por sua vez, a expansão das matrículas públicas precisaria ser de 1,36 milhão para atingir a meta do PNE. No segmento privado, a necessidade de expansão para cumprir a meta da TBM seria praticamente satisfeita com a redução da desistência pela metade. 


\subsection{CENÁRIOS DE IMPACTO DA REDUÇÃO DA TAXA DE DESISTÊNCIA E DA TAXA DE OCIOSIDADE SOBRE A NECESSIDADE DE NOVAS VAGAS}

Para que o segmento privado cumpra seu papel na elevação da taxa bruta de matrículas do ensino superior, bastaria que a ociosidade dos cursos privados fosse reduzida $37,6 \%$ ou que a taxa de desistência dos cursos caísse em pouco mais da metade. No segmento público, mesmo com a redução da ociosidade e da desistência dos cursos ainda seria necessária a criação de novas vagas para atingir a meta do PNE. O efeito combinado da redução da desistência com a redução da ociosidade no segmento público é apresentado no Gráfico 18.

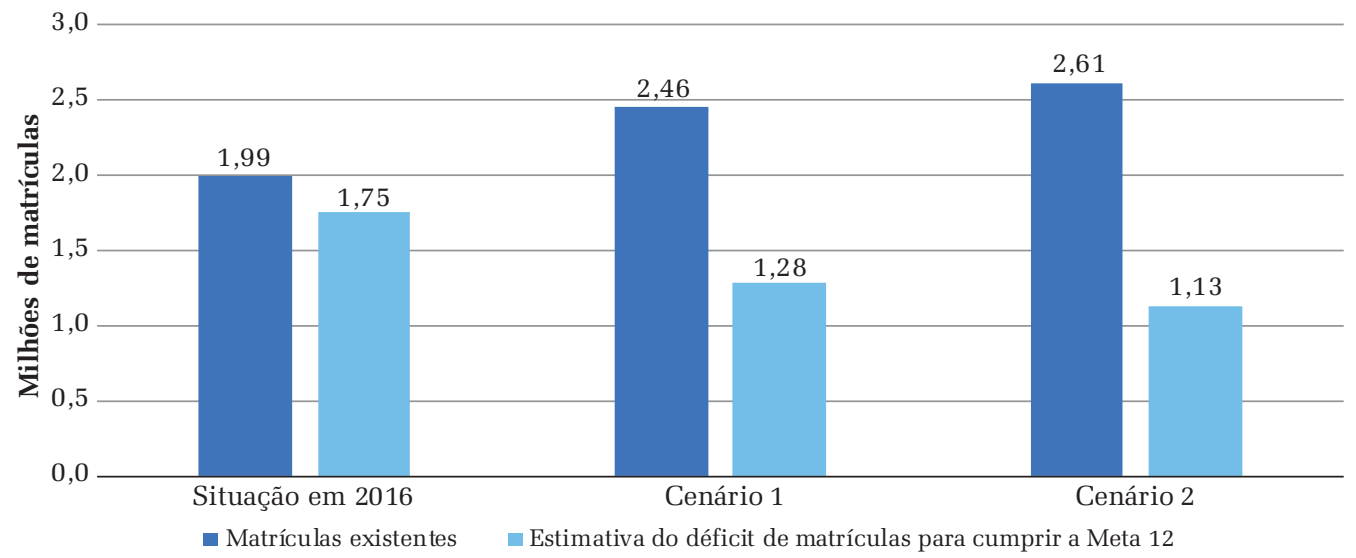

GRÁFICO 18

\section{CENÁRIOS PARA O AUMENTO DAS MATRÍCULAS PELA DIMINUIÇÃO DA OCIOSIDADE DE VAGAS INICIAIS E DAS DESISTÊNCIAS* - BRASIL}

Fonte: Elaboração própria com base em dados do Censo da Educação Superior (2010-2016) e da Pnad Contínua (2017) - $2^{\circ}$ trimestre/IBGE.

* No primeiro cenário a ociosidade e a desistência são reduzidas à metade. No segundo cenário, a um terço.

É possível fazer uma estimativa da quantidade de novos ingressantes e de novas vagas para alcançar os objetivos de expansão do segmento público. Em 2016, a proporção de matrículas por ingressante no segmento público foi de 4,14 e a taxa de ociosidade de vagas iniciais de 15\%. Na atual situação (2016), haveria a necessidade de 422,3 mil ingressantes adicionais no segmento público e a criação de 496,8 mil vagas iniciais. Com a redução da desistência e da ociosidade pela metade, a proporção de matrículas por ingressante subiria para 4,70 e a taxa de ociosidade cairia para 7,5\%. Nesse cenário, seriam necessários 273,2 mil ingressantes adicionais, incorporados ao segmento público de educação superior com a criação de 295,3 mil vagas iniciais. Em um segundo cenário, de redução de dois terços da ociosidade de vagas iniciais e da desistência, a proporção de matrículas por ingressante subiria para 4,87 e a taxa 
de ociosidade seria reduzida a 5,0\%. Nesse cenário, a necessidade de ingressantes adicionais no segmento público, em relação ao patamar de 2016, seria de 231,9 mil e precisariam ser criadas 244,1 mil vagas iniciais.

\subsection{CENÁRIOS DE IMPACTO DA REDUÇÃO DAS TAXAS DE DESISTÊNCIA E OCIOSIDADE E DA AMPLIAÇÃO DE VAGAS EM CURSOS NOTURNOS SOBRE A NECESSIDADE DE NOVAS VAGAS}

Por fim, pode-se incorporar ao cálculo o potencial de expansão noturna dos cursos públicos que ofertam mais vagas no período matutino e vespertino, otimizando a capacidade já instalada. Com a criação de 65,2 mil vagas no período noturno nesses cursos, a necessidade de criação de vagas adicionais cairia para 230,1 mil no primeiro cenário e para 178,9 mil no segundo cenário. Com a expansão do turno noturno no grupo de cursos analisados na Tabela 2, o número de vagas iniciais no segmento público que precisariam ser criadas cairia em 53,7\%, no primeiro cenário, e em 64,0\%, no segundo cenário em relação ao patamar atual (2016) - ver Gráfico 19 e Tabela A2 do Apêndice A para maiores detalhes. Em ambos os cenários, a quantidade de vagas supera a de ingressantes por se assumir a existência de ociosidade de vagas nos patamares fixados pelos cenários.

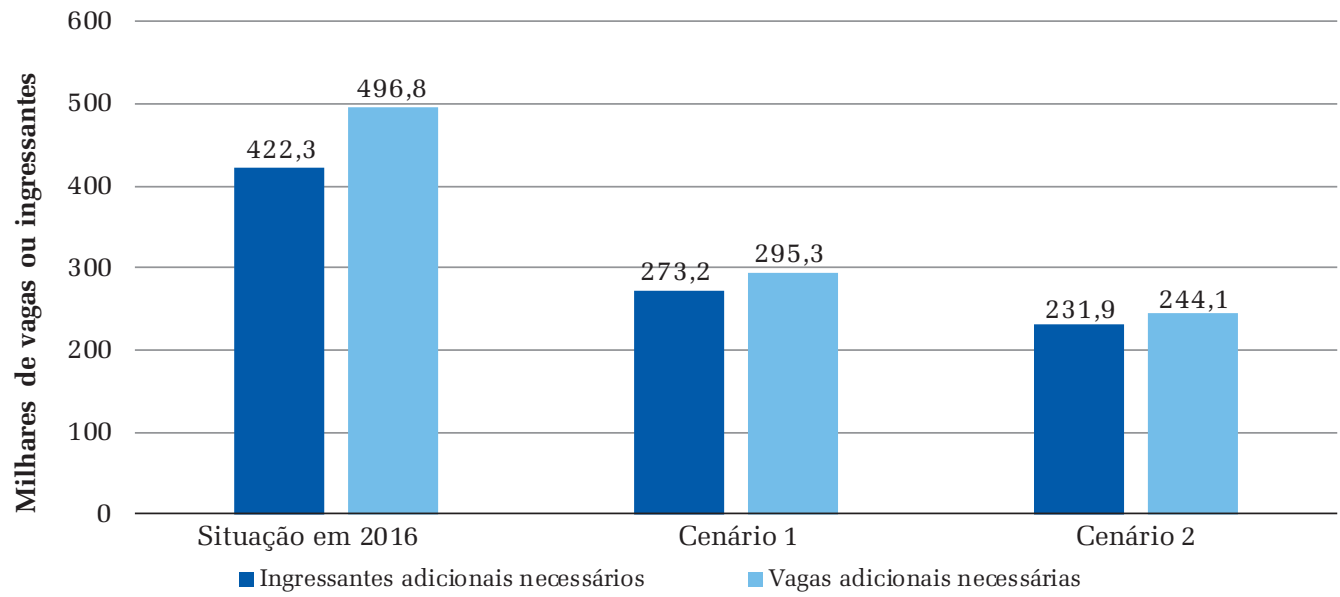

GRÁFICO 19

NECESSIDADE DE NOVAS VAGAS E DE NOVOS INGRESSANTES NO SEGMENTO PÚBLICO PARA CUMPRIR OS OBJETIVOS DA META $12^{*}$ - BRASIL

Fonte: Elaboração própria com base em dados do Censo da Educação Superior (2010-2016)

* No primeiro cenário a ociosidade e a desistência são reduzidas à metade. No segundo cenário, a um terço. 


\section{CONSIDERAÇÕES FINAIS}

Este artigo procurou contribuir para o monitoramento da Meta 12 do PNE de três maneiras complementares. Primeiro, identificando, em termos de quantidade de alunos e matrículas, o quão distante o País se encontra de atingir a Meta 12. Segundo, construindo indicadores úteis para o monitoramento das Estratégias 12.3 e 12.17 do PNE. Terceiro, produzindo cenários retrospectivos sobre o quanto a melhoria desses indicadores poderia impactar na expansão das matrículas de graduação, com vistas ao cumprimento dos objetivos centrais da Meta 12.

Constatou-se que é preciso incluir 3,51 milhões de alunos nos cursos de graduação, para o alcance de um total de 11,42 milhões de alunos até 2024, e garantir o acesso de mais 2,24 milhões de jovens de 18 a 24 anos à educação superior, somando um total de 7,53 milhões de pessoas dessa faixa etária que estejam cursando ou já tenham concluído esse nível de ensino ao final do PNE. Adicionalmente, estima-se que para garantir os dois objetivos anteriores, alcançando-se as metas para as taxas brutas e líquidas de matrículas, será necessário alcançar 11,65 milhões de matrículas ativas nos cursos de graduação em 2024, o que representaria um acréscimo de 3,60 milhões de matrículas em relação aos níveis de 2016. Desse total de matrículas adicionais, 1,75 milhão precisará ocorrer no segmento público e 1,85 milhão no segmento privado de educação superior.

Dentre os objetivos do PNE para a educação superior, a expansão de matrículas no segmento público é o que se encontra mais distante de ser efetivado, sendo necessário um aumento de 87,9\% em relação ao patamar de matrículas públicas observado em 2016. Apesar do tamanho desse desafio, o próprio PNE prevê algumas estratégias para superá-lo, tendo em vista a capacidade já instalada nas IES públicas. Três dessas estratégias foram consideradas nesse estudo: a redução da ociosidade de vagas, a elevação da taxa de conclusão e a ampliação da oferta em cursos noturnos. Para isso, realizaram-se os cálculos de cada um desses indicadores, que trazem luz sobre aspectos importantes da realidade dos cursos de graduação no País.

Com base em estimativas, constatou-se que, apesar do baixo acesso da população brasileira à educação superior e de o número de candidatos à graduação superar o número de vagas ofertadas, há um elevado percentual de vagas iniciais ociosas. Nos cursos públicos, a taxa média de ociosidade das vagas iniciais, em 2016, foi de 15,0\%, enquanto nos cursos privados foi de 69,5\%. Além disso, observou-se que grande parte dos alunos que ingressaram na graduação não conseguiram obter o diploma nos cursos em que iniciaram os estudos. Por meio do acompanhamento longitudinal da coorte de ingressantes de 2010, constatou-se que apenas 45,8\% dos estudantes das IES públicas e 41,1\% das IES privadas haviam concluído seus cursos de origem após um período de sete anos. Nos cursos públicos presenciais, a taxa média de desistência no período foi de $43,5 \%$ e nos privados de $55,6 \%$. 
A análise realizada identificou ainda similaridades entre a ociosidade de vagas e a desistência do curso. Ambas têm menor incidência nas IES públicas e em cursos de maior prestígio e retorno econômico, com destaque para os cursos de medicina. Mas a principal semelhança talvez seja que ambas têm um caráter sistêmico, distribuindo-se nas mais diversas áreas do conhecimento e tipos de instituição. Entretanto, a ociosidade de vagas, em especial no segmento público, pode ser mais fácil de ser solucionada, uma vez que $36,6 \%$ dos cursos públicos apresentam taxa de ociosidade de vagas novas igual a zero. Todavia, saber como solucionar essa questão requer mais investigações. No caso da ociosidade de vagas na graduação, são ainda escassas as pesquisas sobre suas causas, tanto no Brasil quanto no exterior.

Já a produção bibliográfica sobre as taxas de desistência/evasão é mais extensa. Ela revela que o fenômeno das altas taxas de desistência dos cursos não se restringe ao Brasil, existindo também nos mais variados países (Bound; Turner, 2011). A análise aqui apresentada mostrou que apenas 1,4\% dos cursos públicos tem taxa de conclusão superior a 90\%, indicando que o objetivo traçado pela Estratégia 12.3 do PNE pode ser pouco realista, embora desejável. Assim como no caso da ociosidade de vagas, também são necessárias mais pesquisas que investiguem e expliquem as causas das elevadas taxas de desistência e que, principalmente, identifiquem mecanismos para mitiga-las.

No que diz respeito à expansão das vagas nos cursos públicos noturnos, verificou-se que o objetivo traçado pela Estratégia 12.3 do PNE já foi atingido. Em 2016, 41,8\% das vagas públicas presenciais foram ofertadas no período noturno. Não obstante, foi identificada a existência de 1.438 cursos públicos que ofertam mais vagas no período matutino ou vespertino em relação ao período noturno. Esses cursos poderiam criar mais de 65 mil vagas noturnas aproveitando a infraestrutura física existente, ainda que deva se considerar uma eventual contratação adicional de professores e outros profissionais.

Por fim, este artigo apresentou cenários para o alcance das metas do PNE, com vistas ao cumprimento dos objetivos da Meta 12, com base em indicadores que não requerem a extensão da capacidade já instalada, ou seja, por meio de redução na taxa de ociosidade, das taxas de desistência e da ampliação das vagas em cursos noturnos. Estima-se que, nas IES privadas, a redução da ociosidade de vagas iniciais em 37,6\% ou a redução da taxa de desistência em 51\% seja suficiente para criar 1,85 milhão de matrículas, garantindo que esse segmento cumpra com sua parte na expansão mínima de matrículas previstas pelo PNE. Já para o segmento público, mesmo com a ampliação das 65.179 vagas noturnas e com uma redução hipotética em dois terços das taxas de ociosidade e de desistência, ainda assim seria necessária a criação de 178,9 mil vagas iniciais adicionais. 


\section{REFERÊNCIAS}

ALMEIDA, S. S. Vagas ociosas no ensino superior brasileiro: uma análise dos governos Fernando Henrique Cardoso e Luiz Inácio Lula da Silva e suas repercussões nos anos posteriores. In: COLÓQUIO INTERNACIONAL DE GESTÃO UNIVERSITÁRIA - CIGU, 15., 2015, Mar del Plata. Anais... Florianópolis: UFSC, 2015.

ASSOCIAÇÃO NACIONAL DOS DIRIGENTES DAS INSTITUIÇÕES FEDERAIS DE ENSINO SUPERIOR (Andifes); ASSOCIAÇÃO BRASILEIRA DOS REITORES DAS UNIVERSIDADES ESTADUAIS E MUNICIPAIS (Abruem); BRASIL. Ministério da Educação (MEC). Diplomação, retenção e evasão nos cursos de graduação em instituições de ensino superior públicas: resumo do relatório apresentado a ANDIFES, ABRUEM e SESu/MEC pela Comissão Especial. Avaliação: Revista da Avaliação da Educação Superior, Sorocaba; Campinas, v. 1, n. 2, p. 55-65, 1996.

AZEVEDO, A. R. Políticas para a educação superior e evolução de Indicadores de Qualificação Docente entre 1995 e 2013: um estudo exploratório. In: SEMINÁRIO NACIONAL UNIVERSITAS/BR, 24., 2016, Maringá. Anais... Maringá: UEM, 2016. p. 651-670.

BAGGI, C. A. dos S.; LOPES, D. A. Evasão e avaliação institucional no ensino superior: uma discussão bibliográfica. Avaliação: Revista da Avaliação da Educação Superior, Sorocaba; Campinas, v. 16, n. 2, p. 355-374, jul. 2011.

BARBOSA, J. P. et al. A adoção do SISU e a evasão na Universidade Federal de Uberlândia. Revista Ibero-Americana de Estudos em Educação, Araraquara, v. 12, n. especial, p. 722-738, 4 jun. 2017.

BITTAR, M.; ALMEIDA, C. E. M. D.; VELOSO, T. C. M. A. Ensino noturno e expansão do acesso de estudantes-trabalhadores à educação superior. In: BITTAR, M.; OLIVEIRA, J. F.; MOROSINI, M. (Org.). Educação superior no Brasil: 10 anos pós-LDB. Brasília: Inep, 2008. p. 89-110.

BOUND, J.; TURNER, S. Dropouts and diplomas: the divergence in collegiate outcomes. In: HANUSHEK, E. A.; MACHIN, S. J.; WOESSMANN, L. (Ed.). Handbook of the Economics of Education. Amsterdam: Elsevier, 2011. p. 573-613. v. 4.

BRAGA, M. M.; MIRANDA-PINTO, C. O.; CARDEAL, Z. D. Perfil sócio-econômico dos alunos, repetência e evasão no curso de química da UFMG. Química Nova, Belo Horizonte, v. 20, n. 4, p. 438-444, 1997. 
BRASIL. Constituição (1988). Constituição da República Federativa do Brasil. Brasília: Senado Federal, 1988.

BRASIL. Lei $\mathrm{n}^{\circ}$ 9.394, de 20 de dezembro de 1996. Estabelece as diretrizes e bases da educação nacional. Diário Oficial da União, Brasília, DF, 23 dez. 1996. Seção 1, p. 27833.

BRASIL. Lei $\mathrm{n}^{\mathrm{0}}$ 10.172, de 9 de janeiro de 2001. Aprova o Plano Nacional de Educação e dá outras providências. Diário Oficial da União, Brasília, DF, 10 jan. 2001. Seção 1, p. 1-20.

BRASIL. Lei $\mathrm{n}^{0}$ 11.892, de 29 de dezembro de 2008. Institui a Rede Federal de Educação Profissional, Científica e Tecnológica, cria os Institutos Federais de Educação, Ciência e Tecnologia, e dá outras providências. Diário Oficial da União, Brasília, DF, 30 dez. 2008. Seção 1, p. 1-3.

BRASIL. Lei $\mathrm{n}^{\circ}$ 13.005, de 25 de junho de 2014. Aprova o Plano Nacional de Educação - PNE e dá outras providências. Diário Oficial da União, Brasília, DF, 26 jun. 2014. Seção 1, p. 1.

BRASIL. Instituto Nacional de Estudos e Pesquisas Educacionais Anísio Teixeira (Inep). Portaria $n^{\circ} 424$, de 9 de outubro de 2015. Propõe consulta pública para coletar contribuições para o aprimoramento dos indicadores selecionados para o monitoramento e avaliação do Plano Nacional de Educação (2014-2024). Diário Oficial da União, Brasília, DF, n. 195, 13 out. 2015a. Seção 1, p. 15.

BRASIL. Instituto Nacional de Estudos e Pesquisas Educacionais Anísio Teixeira (Inep). Manual do usuário do Censo da Educação Superior 2015. Brasília, 2015b.

BRASIL. Instituto Nacional de Estudos e Pesquisas Educacionais Anísio Teixeira (Inep). Relatório do $1^{\circ}$ Ciclo de Monitoramento das Metas do PNE: biênio 2014-2016. Brasília, 2016.

BRASIL. Instituto Nacional de Estudos e Pesquisas Educacionais Anísio Teixeira (Inep). Indicadores educacionais: indicador de fluxo da educação superior.

Brasília, 2017a. Disponível em: <http://portal.inep.gov.br/web/guest/indicadoreseducacionais >. Acesso em: 20 dez. 2017.

BRASIL. Instituto Nacional de Estudos e Pesquisas Educacionais Anísio Teixeira (Inep). Metodologia de cálculo dos indicadores de fluxo da educação superior. Brasília, 2017b.

BRASIL. Instituto Nacional de Estudos e Pesquisas Educacionais Anísio Teixeira (Inep). Censo da Educação Superior: microdados: 2010-2016. Brasília, 2017c. Disponível em: <http://portal.inep.gov.br/web/guest/microdados>. Acesso em: 17 maio 2019. 
BRASIL. Instituto Nacional de Estudos e Pesquisas Educacionais Anísio Teixeira (Inep). Relatório do $2^{\circ}$ Ciclo de Monitoramento das Metas do Plano Nacional de Educação - 2018. Brasília, 2018.

BRITO, M. M. A. A dependência na origem: desigualdades no sistema educacional brasileiro e a estruturação social das oportunidades. 2014. 270 f. Tese (Doutorado em Sociologia) - Faculdade de Filosofia, Letras e Ciências Humanas, Universidade de São Paulo, São Paulo, 2014.

CARDOSO, C. B. Efeitos da política de cotas na Universidade de Brasília: uma análise do rendimento e da evasão. 2008. 134 f. Dissertação (Mestrado em Educação) Faculdade de Educação, Universidade de Brasília, Brasília, 2008.

CASEIRO, L. C. Z. Avaliação de cenários para o cumprimento dos objetivos de expansão da educação superior segundo o plano nacional de educação 2014-2024. Boletim na Medida, Brasília, ano 5, n. 9, p. 5-10, mar. 2016a.

CASEIRO, L. C. Z. Desigualdade de acesso à educação superior no Brasil e o Plano Nacional de Educação. Brasília: Inep, 2016b. (Série PNE em Movimento, n. 3).

CASEIRO, L. C. Z.; AZEVEDO, A. R. A construção dos indicadores de monitoramento da Meta 12 do PNE. In: BOF, A. M.; OLIVEIRA, A. S. (Org.). Cadernos de estudos e pesquisas em políticas educacionais. Brasília: Inep, 2018. p. 213-240. v. 1.

CUNHA, A. M.; TUNES, E.; SILVA, R. R. Evasão do curso de química da Universidade de Brasília: a interpretação do aluno evadido. Química Nova, Belo Horizonte, v. 24, n. 1, p. 262-280, 2001.

DOURADO, L. F. Plano Nacional de Educação: política de estado para a educação Brasileira. Brasília: Inep, 2016.

INSTITUTO BRASILEIRO DE GEOGRAFIA E ESTATÍSTICA (IBGE). Pesquisa Nacional por Amostra de Domicílios (Pnad Contínua): microdados 2012-2017. Disponível em: <https:/www.ibge.gov.br/estatisticas/sociais/trabalho/9173-pesquisanacional-por-amostra-de-domicilios-continua-trimestral.html $?=\& \mathrm{t}=$ microdados $>$. Acesso em: 8 maio 2019.

INSTITUTO BRASILEIRO DE GEOGRAFIA E ESTATÍSTICA (IBGE). Projeções populacionais. 2018. Disponível em: <https:/www.ibge.gov.br/estatisticas/sociais/ populacao/9109-projecao-da-populacao.html? edicao $=21830 \& \mathrm{t}=$ resultados $>$. Acesso em: 4 set. 2018.

JANNUZZI, P. M. Indicadores sociais no Brasil. Campinas: Alínea; PUC-Campinas, 2001. 
MEDEIROS, M.; BARBOSA, R. J.; CARVALHAES, F. A. O. Educação, desigualdade e redução da pobreza no Brasil. Brasília; Rio de Janeiro: IPEA, 2019. (Texto para Discussão, v. 2447).

MOROSINI, M. C. et al. A evasão na educação superior no Brasil: uma análise da produção de conhecimento nos periódicos Qualis entre 2000-2011. In: ANDOAÍN, J. A. G. de et al. ICLABES: Primera Conferencia Latinoamericana sobre el Abandono en la Educación Superior. Madrid: E.U.I.T. de Telecomunicación, 2012. p. 65-74.

ORGANISATION FOR ECONOMIC CO-OPERATION AND DEVELOPMENT (OECD). Education at a Glance 2018: OECD indicators. Paris: OECD Publishing, 2018. Available: <https://www.oecd-ilibrary.org/docserver/eag-2018-en.pdf?expires $=155$ 8096386\&id =id\&accname $=$ guest $\&$ checksum $=$ 93C5D694C6FCE0CB6FA524F654E 509D9 >. Access in: 13 May 2019.

PACHECO, E.; RISTOFF, D. I. Educação superior: democratizando o acesso. Brasília: Inep, 2004. (Série Documental: Textos para Discussão, 12).

RABELO, R. P.; CAVENAGHI, S. M. Indicadores educacionais para formação de docentes: uso de dados longitudinais. Estudos em Avaliação Educacional, São Paulo, v. 27 , n. 66 , p. 816-850, set./dez. 2016.

RIBEIRO, C. A. C.; CENEVIVA, R.; BRITO, M. M. A. Estratificação educacional entre jovens no Brasil: 1960 a 2010. In: ARRETCHE, M. (Ed.). Trajetórias das desigualdades: como o Brasil mudou nos últimos cinquenta anos. São Paulo: Unesp, 2015. Cap. 3.

RIBEIRO, M. A. O projeto profissional familiar como determinante da evasão universitária: um estudo preliminar. Revista Brasileira de Orientação Profissional, Porto Alegre, v. 6, n. 2, p. 55-70, 2005.

SARAIVA, A. M. A. Taxa de matrícula bruta. In: OLIVEIRA, D. A.; DUARTE, A. M. C.; VIEIRA, L. M. F. Dicionário: trabalho, profissão e condição docente. Belo Horizonte: Faculdade de Educação/UFMG, 2010a. 1 CD-ROM.

SARAIVA, A. M. A. Taxa de matrícula líquida. In: OLIVEIRA, D. A.; DUARTE, A. M. C.; VIEIRA, L. M. F. Dicionário: trabalho, profissão e condição docente. Belo Horizonte: Faculdade de Educação/UFMG, 2010b. 1 CD-ROM.

SANTOS, R. Os desafios da Meta 8 do PNE: juventude, raça/cor, renda e territorialidade. Brasília: Inep, 2016. (Série PNE em Movimento, 2).

SILVA FILHO, R. L. et al. A evasão no ensino superior brasileiro. Cadernos de Pesquisa, São Paulo, v. 37, n. 132, p. 641-659, 2007. 
SOUZA, J. V. Vagas ociosas na educação superior brasileira no período 2003-2010: novas variáveis em jogo? Tópicos Educacionais, Recife, v. 19, n. 1, p. 119-146, jan./ jun. 2013.

TINTO, V. Completing college: rethinking institutional action. Chicago: The University of Chicago Press, 2012.

TINTO, V. Leaving college: rethinking the causes and cures of student attrition.

Chicago: The University of Chicago Press, 1993.

UNITED NATIONS EDUCATIONAL, SCIENTIFIC AND CULTURAL

ORGANIZATION (UNESCO). UNdata: a world of information. 2017. Available in: <http://data.un.org >. Access in: 20 Aug. 2017. 


\section{APÊNDICES}

\section{APÊNDICE A - TABELAS}

TABELA A1

CORRELAÇÃO ENTRE TAXA DE OCIOSIDADE DE VAGAS INICIAIS E RELAÇÃO CANDIDATO/VAGA - BRASIL

\begin{tabular}{|c|c|c|c|}
\hline & & $\begin{array}{l}\text { Relação candidato/ } \\
\text { vaga nova }\end{array}$ & $\begin{array}{c}\text { Taxa de ociosidade } \\
\text { de vagas iniciais }\end{array}$ \\
\hline \multirow{3}{*}{$\begin{array}{l}\text { Relação candidato/vaga } \\
\text { nova }\end{array}$} & $\begin{array}{l}\text { Correlação de } \\
\text { Pearson }\end{array}$ & 1 &,$- 148^{*}$ \\
\hline & Sig. & & ,000 \\
\hline & $\mathrm{N}$ & 7700 & 7700 \\
\hline \multirow{3}{*}{$\begin{array}{l}\text { Taxa de ociosidade de } \\
\text { vagas iniciais }\end{array}$} & $\begin{array}{l}\text { Correlação de } \\
\text { Pearson }\end{array}$ &,$- 148^{*}$ & 1 \\
\hline & Sig. & ,000 & \\
\hline & $\mathrm{N}$ & 7700 & 7700 \\
\hline
\end{tabular}

Fonte: Elaboração própria.

* Correlação é significante para $\alpha<0,01$.

TABELA A2

CENÁRIOS PARA OTIMIZAÇÃO DA CAPACIDADE INSTALADA NAS IES PÚBLICAS* - BRASIL

\begin{tabular}{|l|r|r|r|} 
& \multicolumn{1}{|c|}{ (continua) } \\
\hline Meta estimada de matrículas públicas para 2024 & $\begin{array}{c}\text { Situáo } \\
\mathbf{2 0 1 6}\end{array}$ & Cenário 1 & Cenário 2 \\
\hline Matrículas públicas existentes em 2016 & 3.740 .270 & 3.740 .270 & 3.740 .270 \\
\hline Ingressantes em 2016 & 1.990 .078 & 2.456 .206 & 2.611 .582 \\
\hline Taxa Matrícula / Ingressantes & 480.189 & 522.525 & 536.637 \\
\hline Vagas novas em 2016 & 4,14 & 4,70 & 4,87 \\
\hline Vagas novas ociosas em 2016 & 564.861 & 564.861 & 564.861 \\
\hline Taxa de ociosidade & 84.672 & 42.336 & 28.224 \\
\hline & $14,99 \%$ & $7,50 \%$ & $5,00 \%$ \\
\hline
\end{tabular}


TABELA A2

CENÁRIOS PARA OTIMIZAÇÃO DA CAPACIDADE INSTALADA NAS IES PÚBLICAS* - BRASIL

\begin{tabular}{|c|c|c|c|}
\hline & $\begin{array}{c}\text { Situação } \\
2016\end{array}$ & Cenário 1 & Cenário 2 \\
\hline Ingressantes adicionais necessários & 422.306 & 273.167 & 231.927 \\
\hline Vagas adicionais necessárias sem expansão noturna & 496.783 & 295.303 & 244.126 \\
\hline Potencial latente de expansão de vagas noturnas & 65.179 & 65.179 & 65.179 \\
\hline Vagas adicionais necessárias com expansão noturna & 431.604 & 230.124 & 178.947 \\
\hline
\end{tabular}

\section{APÊNDICE B - GRÁFICOS}

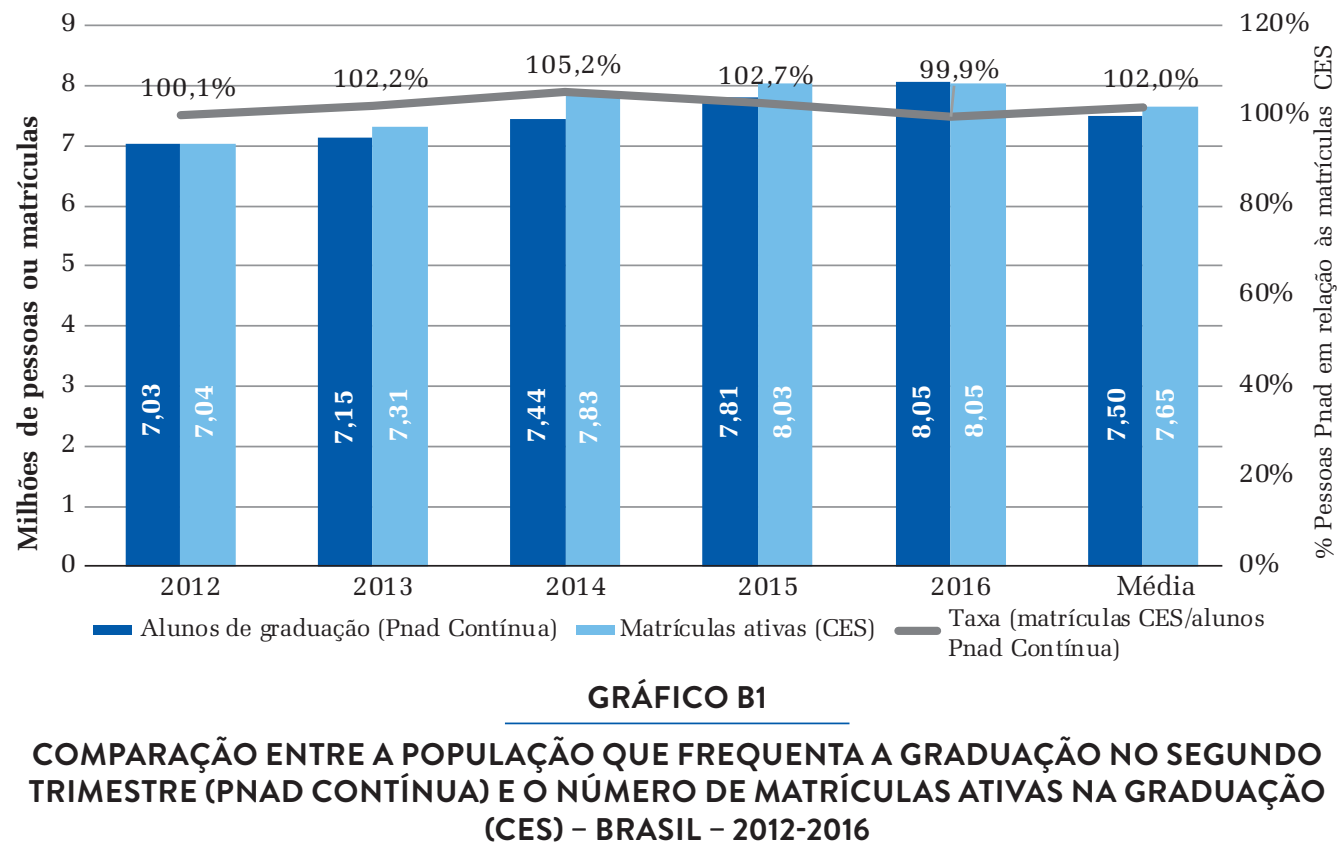

Fonte: Elaboração própria com base em dados da Pnad Contínua/IBGE ( $2^{\circ}$ trimestre) e do Censo de Educação Superior. 


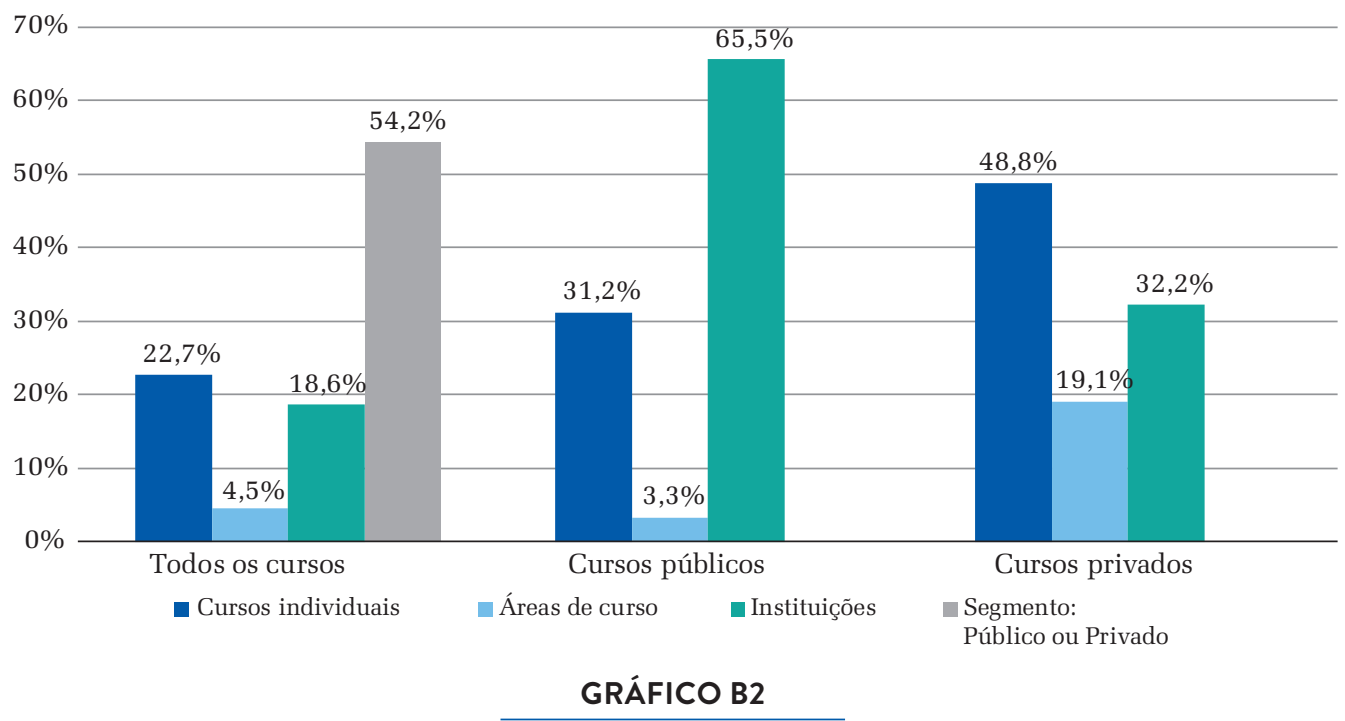

ANÁLISE DE VARIÂNCIA DA TAXA MÉDIA DE OCIOSIDADE DOS CURSOS, POR SEGMENTO DE ENSINO - BRASIL (EM \% DA VARIÂNCIA DA TAXA MÉDIA DE OCIOSIDADE EXPLICADA POR CADA GRUPO/NIIVEL)

Fonte: Elaboração própria com base em dados do Censo de Educação Superior 2016.

$60,0 \%$

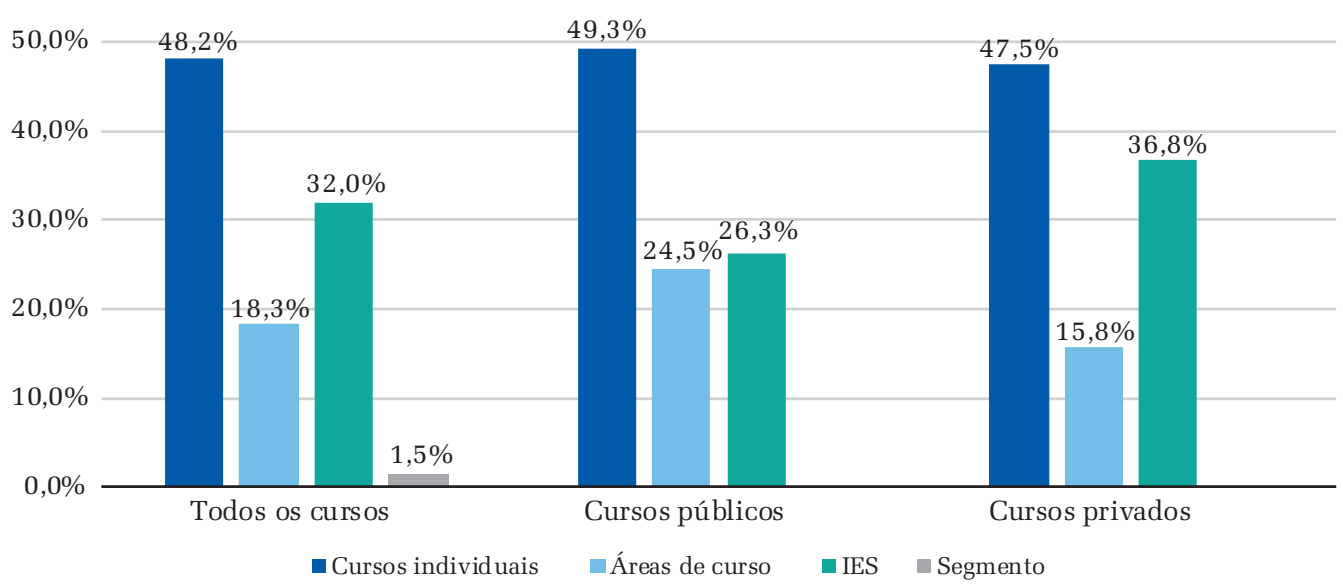

GRÁFICO B3

ANÁLISE DE VARIÂNCIA DA TAXA MÉDIA DE CONCLUSÃO ACUMULADA DOS CURSOS, POR SEGMENTO DE ENSINO - BRASIL - 2010-2016 (EM \% DA VARIÂNCIA DA TAXA MÉDIA DE CONCLUSÃO EXPLICADA POR CADA GRUPO/NIVVEL)

Fonte: Elaboração própria com base em dados do Censo de Educação Superior (2010-2016). 
$60,0 \%$

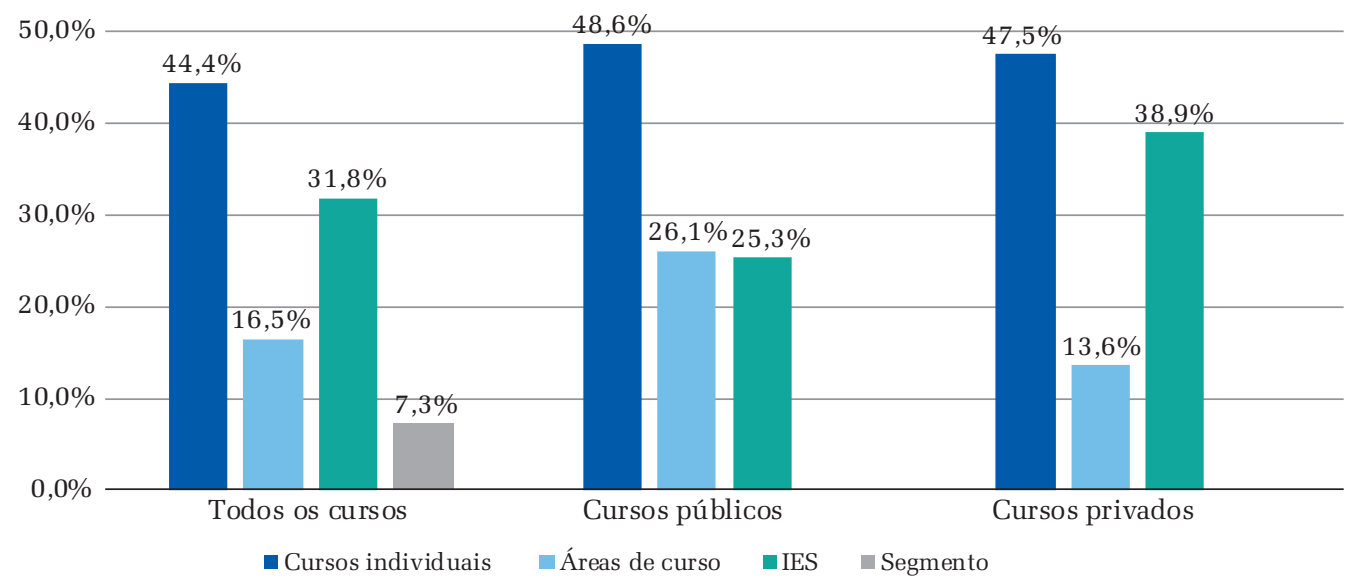

GRÁFICO B4

ANÁLISE DE VARIÂNCIA DA TAXA MÉDIA DE DESISTÊNCIA ACUMULADA DOS CURSOS, POR SEGMENTO DE ENSINO - BRASIL - 2010-2016 (EM \% DA VARIÂNCIA DA TAXA MÉDIA DE DESISTÊNCIA EXPLICADA POR CADA GRUPO/NÍVEL)

Fonte: Elaboração própria com base em dados do Censo de Educação Superior (2010-2016).

$70,0 \%$

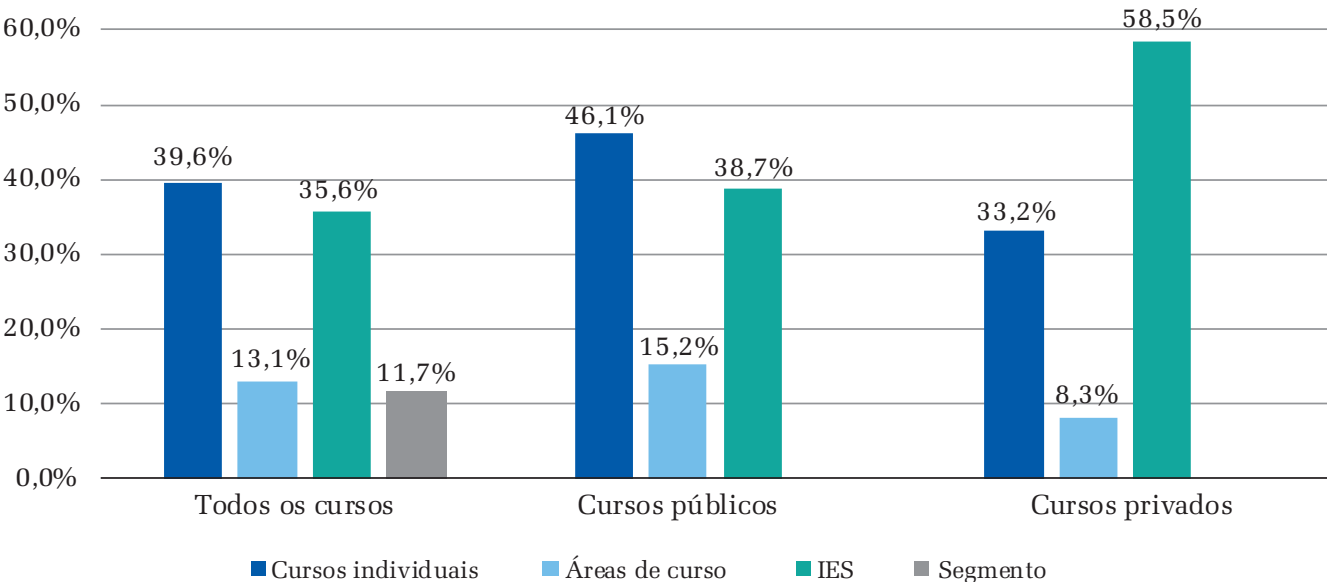

GRÁFICO B5

ANÁLISE DE VARIÂNCIA DA TAXA MÉDIA DE PERMANÊNCIA ACUMULADA DOS CURSOS, POR SEGMENTO DE ENSINO - BRASIL - 2010-2016 (EM \% DA VARIÂNCIA DA TAXA MÉDIA DE PERMANÊNCIA EXPLICADA POR CADA GRUPO/NÍVEL)

Fonte: Elaboração própria com base em dados do Censo de Educação Superior (2010-2016). 


\section{APÊNDICE C}

\section{NOTA METODOLÓGICA PARA O ACOMPANHAMENTO LONGITUDINAL DOS ALUNOS NO CES DE 2010 A 2016}

Procurou-se replicar, em grande parte, neste artigo, a metodologia de construção dos indicadores de fluxo nos cursos de graduação, realizada pela Deed/Inep, descrita em documento publicado pelo órgão e disponível em seu portal na internet (Brasil. Inep, 2017)*. Em ambos os casos os indicadores de fluxo foram construídos por meio do acompanhamento dos alunos ingressantes em 2010 nos cursos em que estavam matriculados. Entretanto, há duas principais diferenças na metodologia adotada neste artigo em relação àquela.

A primeira diferença é que, para os indicadores construídos neste artigo, foram desconsiderados os cursos que não tinham uma trajetória contínua entre os anos de 2010 e 2016, ou seja, cursos que desapareciam do CES de um ano para o outro. Para isso, foi utilizada, assim como na construção dos indicadores de fluxo oficiais (Brasil. Inep, 2017)*, uma base que contém a correspondência de cursos que mudam de código ao longo dos censos, denominados "cursos representados”. Apesar da utilização desse para-dado com as correspondências dos códigos de curso, foi constatado, no acompanhamento da trajetória dos cursos, que cerca de 11,5\% dos cursos existentes em 2010 desapareciam das bases do CES até o ano de 2016. As causas desse desaparecimento podem ser diversas, desde erros no fornecimento das informações, até o fechamento real do curso. A investigação dessas causas, contudo, está além do escopo deste artigo. Esses cursos foram excluídos da análise, uma vez que não parecia correto atribuir a situação de "desistente" aos alunos que desapareceram das bases porque seu curso deixou de existir.

A segunda diferença ocorre no identificador do curso. Com o mesmo objetivo de acompanhar a trajetória dos alunos no interior dos cursos de graduação, optou-se por construir um novo indicador único para os cursos, ao invés da variável "código de curso" disponível no CES. Essa escolha se deveu ao fato de que muitas vezes um mesmo curso ofertado por uma IES pode possuir mais de um código para diferentes turnos de oferta (matutino, vespertino ou noturno) em um mesmo ano do CES. Por essa razão, o acompanhamento da trajetória dos alunos por meio do "código do curso" pode acabar por atribuir a situação de "desistente" a um aluno que simplesmente mudou de turno dentro do mesmo curso. A solução para a construção de um novo indicador foi a concatenação das variáveis relativas ao código da modalidade de ensino, ao código da IES, ao código área do curso (código OCDE) e ao código do município de oferta do curso. Desse modo, um aluno que se encontrava matriculado, em 2010, por exemplo, em um curso presencial (modalidade de ensino) de formação de professores em 
matemática (código OCDE), em uma instituição de um determinado município, não foi considerado como desistente caso estivesse matriculado em um curso com essas mesmas características nos anos seguintes, mesmo que o código do curso houvesse mudado. No caso dos cursos na modalidade a distância, o identificador construído não contém o código do município. Ou seja, nos cursos a distância, a permanência no mesmo município de oferta não é exigida para considerar que o aluno permaneceu vinculado ao curso de um ano para o outro, bastando que ele se encontrasse matriculado na mesma área de curso, na mesma IES e na mesma modalidade de ensino.

A construção do novo indicador único de curso não foi trivial do ponto de vista operacional, pois foi constatada a existência de cursos que mudavam de código OCDE e de código de IES ao longo dos anos. Por esse motivo, foi necessário primeiro criar uma tabela com as correspondências de código OCDE e código de IES para cada curso ao longo dos anos. A mudança de código de IES se deve a processos de fusão e aquisição de IES. Adotando procedimento semelhante ao da construção dos indicadores oficiais, considerou-se a informação do último CES disponível como sendo a mais atual e com maior probabilidade de estar correta (para os casos de erros de preenchimento do código OCDE).

Assim, utilizando o identificador de curso construído, adotou-se os mesmos procedimentos da construção dos indicadores oficiais, acompanhando os alunos ingressantes em 2010 ao longo dos CES, por meio do código de aluno e do identificador de curso. Para seleção dos ingressantes em 2010, checou-se a consistência da informação do ano de ingresso para cada aluno entre 2010 e 2016. A situação dos alunos dentro do curso foi monitorada por meio da variável "código de situação do aluno no curso" (CO_ALUNO_SITUACAO), que indica se o aluno estava cursando, se tinha matrícula trancada, se foi desvinculado do curso, transferido para outro curso da mesma IES, se havia formado ou se havia falecido enquanto matriculado. As situações de "cursando" e "trancado" foram consideradas como permanência no curso; as situações de "desvinculado" e "transferido" foram entendidas como desistente do curso; e a situação de "formado", como concluinte. Os alunos que faleceram foram retirados da análise. Para maiores detalhes, consultar o documento Metodologia de cálculo dos indicadores de fluxo da educação superior (Brasil. Inep, 2017)*.

\footnotetext{
* BRASIL. Instituto Nacional de Estudos e Pesquisas Educacionais Anísio Teixeira (Inep). Metodologia de cálculo dos indicadores de fluxo da educação superior. Brasília, 2017.
} 